CrossMark

\&lick for updates

Cite this: Dalton Trans., 2015, 44 19218

\title{
Synthesis and properties of mono- and dimetal Fischer multicarbene complexes derived from thiophene and thieno[2,3-b]thiophene $\uparrow$
}

\author{
Zandria Lamprecht, Nina A. van Jaarsveld, Daniela I. Bezuidenhout, David C. Liles \\ and Simon Lotz*
}

\begin{abstract}
Access to multicarbene complexes of a fused thienothiophene substrate was obtained by the use of the tetrabrominated thieno[2,3-b]thiophene precursor in a lithium-bromide exchange reaction, followed by nucleophilic attack on metal hexacarbonyls $(\mathrm{M}=\mathrm{Cr}$, W). Subsequent alkylation afforded unique triscarbene complexes $\left[\mathrm{M}(\mathrm{CO})_{4}\left\{\{\mathrm{C}(\mathrm{OEt})\}_{2} \mathrm{C}_{6} \mathrm{H}_{1} \mathrm{~S}_{2} \mathrm{C}(\mathrm{OEt})\right\} \mathrm{M}(\mathrm{CO})_{5}\right](\mathrm{M}=\mathrm{Cr}$ 12, W 13) featuring three non-equivalent carbene ligands on a single thiophene linker, as well as the bischelated tetracarbene complexes $\left.\left[\mathrm{M}(\mathrm{CO}){ }_{4}\{\mathrm{C}(\mathrm{OEEt})\}_{2} \mathrm{C}_{6} \mathrm{~S}_{2}\{\mathrm{C}(\mathrm{OEt})\}_{2}\right\} \mathrm{M}(\mathrm{CO})_{4}\right](\mathrm{M}=\mathrm{Cr} 14, \mathrm{~W} 15)$. The triscarbene complexes 12 and 13 are the first examples of multi-alkoxycarbene complexes featuring three non-equivalent carbene ligands. The reaction also afforded the chelated mononuclear biscarbene complexes $\left[\mathrm{M}(\mathrm{CO}){ }_{4}\{\mathrm{C}(\mathrm{OEt})\}_{2} \mathrm{C}_{6} \mathrm{H}_{2} \mathrm{~S}_{2}\right](\mathrm{M}=$ $\mathrm{Cr}$ 10, W 11) in low yields. Similarly, employing tetrabromothiophene as precursor yielded the mononuclear chelate biscarbene complexes $\left[\mathrm{M}(\mathrm{CO})_{4}\{\mathrm{C}(\mathrm{OEt})\}_{2} \mathrm{C}_{4} \mathrm{H}_{2} \mathrm{~S}\right](\mathrm{M}=\mathrm{Cr}$ 6, W 7) and the dinuclear tetracarbene complexes $\left[\mathrm{M}(\mathrm{CO})_{4}\left\{\{\mathrm{C}(\mathrm{OEt})\}_{2} \mathrm{C}_{4} \mathrm{~S}\{\mathrm{C}(\mathrm{OEt})\}_{2}\right\} \mathrm{M}(\mathrm{CO})_{4}\right](\mathrm{M}=\mathrm{Cr} \mathbf{8}, \mathrm{W}$ 9). Modification of the classic Fischer carbene synthetic methodology to a process of stepwise additions of lithiating agent and metal carbonyls to thieno[2,3-b]thiophene, facilitates the formation of the mixed metal biscarbene complex $\left[\mathrm{W}(\mathrm{CO})_{5} \mathrm{C}(\mathrm{OEt})\left\{\mathrm{C}_{6} \mathrm{H}_{2} \mathrm{~S}_{2}\right\} \mathrm{C}(\mathrm{OEt}) \mathrm{Cr}(\mathrm{CO})_{5}\right] \mathbf{5}$, as analogue of the homonuclear biscarbene complexes $\left[\mathrm{M}(\mathrm{CO}){ }_{5} \mathrm{C}(\mathrm{OEt})\left\{\mathrm{C}_{6} \mathrm{H}_{2} \mathrm{~S}_{2}\right\} \mathrm{C}(\mathrm{OEt}) \mathrm{M}(\mathrm{CO})_{5}\right],\left(\mathrm{M}=\mathrm{Cr} 3, \mathrm{~W}\right.$ 4). The monocarbene complexes [M(CO) ${ }_{5}\{\mathrm{C}(\mathrm{OEt})-$ $\left.\mathrm{C}_{6} \mathrm{H}_{3} \mathrm{~S}_{2}\right\}$ ), ( $\left.\mathrm{M}=\mathrm{Cr} 1, \mathrm{~W} 2\right)$ were also obtained in high yields, and the molecular structures of the tungsten complexes, with the exception of $\mathbf{9}$ and $\mathbf{1 1}$, were confirmed by single crystal X-ray diffraction studies.
\end{abstract}

Received 11th September 2015 Accepted 9th October 2015

DOI: $10.1039 / c 5 d t 03555 d$

www.rsc.org/dalton

formation. ${ }^{3}$ The preparation of a mononuclear bisalkoxycarbene chelate is challenging because the Fischer porcedure requires a 1,2-dianion on the substrate during the synthesis. The proximity problem of dianions in benzene and olefins has been addressed previously by the successful preparation of the first examples of symmetrically substituted biscarbene chelates (Fig. 1, A). ${ }^{3}$ Dötz and co-workers prepared analogous biscarbene chelates from $N, N^{\prime}$-diphenylhydrazine. ${ }^{4}$ Recently we prepared the first examples of asymmetric bisalkoxycarbene complexes with two carbene ligands in electronically different environments and were surprised to find that the compounds were of relatively high stablility. Examples of such chelating biscarbene complexes attached to a thiophene backbone are

heteroatom-stabilized Fischer carbene complex-types. One way to increase the number of carbene ligands on a single substrate entails the synthesis of biscarbene complexes by sequential or dilithiation of a suitable substrate or by chelate

Department of Chemistry, University of Pretoria, Private Bag X20, Hatfield 0028, Pretoria, South Africa.E-mail: simon.lotz@up.ac.za,daniela.bezuidenhout@up.ac.za †CCDC 1401808 (2), 1401809 (4), 1401810 (5), 1422363 (7), 1401811 (13) and 1401812 (15). For crystallographic data in CIF or other electronic format see DOI: $10.1039 / \mathrm{c} 5 \mathrm{dt} 03555 \mathrm{~d}$

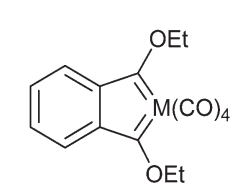

A

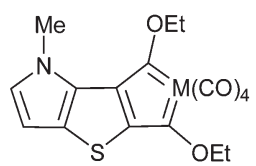<smiles></smiles>

C
Fig. 1 Examples of mononuclear biscarbene chelates. 
shown in Fig. 1 (B and $\mathbf{C}){ }^{5}$ Chelation in $\mathbf{B}$ occurs as a result of the steric and electronic properties of the fused $\mathrm{N}$-methylpyrrole ring, which blocks one side of a thiophene ring and renders the $\beta$-proton of the thiophene ring comparable in acidity to the $\alpha$-proton of the pyrrole ring. Hence, the second deprotonation can occur at either the $\alpha$-position to the nitrogen atom or at the 3-position of the thiophene ring as both the chelate and biscarbene complexes have been isolated from the same reaction. In $\mathbf{C}$, the desired chelation reaction could only be achieved after careful selection of the thiophene substrate. In 2-methyl-4-bromothiophene, a methyl substituent blocks one of the reactive $\alpha$-positions while the bromo-substituent activates the 4-position to accommodate the lithium-bromine exchange reaction and facilitates chelation.

The interest in heteroaromatic sulphur-containing ring systems lies in their electron excessive and planar properties which are transferable to long chain oligo- and polythiophenes, leading to exceptional charge transfer and conductivity in these compounds. ${ }^{6}$ The thiophene units in linear $\alpha$-substituted chains (bithiophene or polythiophenes) tend to retain the thiophene characteristics with regard to proton acidities or even amplify them (charge transfer). In comparison, the planar complexes consisting of fused thiophene rings have a more rigid structure resulting in better overlap of $\mathrm{p}_{\pi^{-}}$ orbitals and therefore show even more efficient $\pi$-resonance effects. ${ }^{7}$ Condensed thienyl rings retain optoelectronic and semiconducting properties but allow for the introduction of other characteristics. These molecules display higher voltage electronic band gaps and greater stability when compared to $\alpha$-oligothiophenes. Unlike the chain structured thiophenes, ${ }^{8}$ annulated thiophenes are rather unexplored when it comes to their organometallic chemistry. ${ }^{9}$ The electron-withdrawing properties of the attached Fischer carbene moieties in combination with the charge transfer properties of thiophenes, hold great promise for potential application in this fast growing area of electronic and photonic thiophene materials. We report herein the syntheses of thieno[2,3- $b]$ thiophene chelates and compare their spectral properties and structural features with the thiophene analogues. This work forms part of an ongoing study of the chemistry of multicarbene and mulitimetal-carbene complexes. ${ }^{10}$

\section{Results and discussion}

Thiophene and thieno[2,3- $b]$ thiophene are commercially available but the latter can be synthesized from trimethylsilyl- 1,3-pentadiyne, ${ }^{11}$ which in turn is accessible from 1,4-bistrimethylsilyl-1,3-butadiyne. ${ }^{12}$ Utilizing the most common Fischer method for the synthesis of metal-carbene complexes, different classes of Fischer carbene complexes could be prepared in this study. Commonly an anionic substrate reacts as a nucleophile with a carbonyl ligand of a neutral metal carbonyl precursor to form a metal acylate. After subsequent alkylation with an appropriate alkylating agent, the neutral Fischer carbene complex is generated. Thiophene and thieno[2,3- $b]$ thiophene were selected as substrates for the lithiations. The first lithiation (deprotonation) occurs at the most acidic protons $\alpha$ to the sulfur atoms while the lithium-halogen exchange reactions will readily include $\beta$-positions. The monoand biscarbene complexes, $\left[\mathrm{M}(\mathrm{CO})_{5}\left\{\mathrm{C}(\mathrm{OEt}) \mathrm{C}_{6} \mathrm{H}_{3} \mathrm{~S}_{2}\right\}\right](\mathrm{M}=\mathrm{Cr} \mathbf{1}$, W 2) and $\left[\mathrm{M}(\mathrm{CO})_{5} \mathrm{C}(\mathrm{OEt})\left\{\mathrm{C}_{6} \mathrm{H}_{2} \mathrm{~S}_{2}\right\} \mathrm{C}(\mathrm{OEt}) \mathrm{M}(\mathrm{CO})_{5}\right](\mathrm{M}=\mathrm{Cr} 3, \mathrm{~W}$ 4), could be prepared in good yields using this method (Scheme 1), whereas the synthesis of the corresponding monoand biscarbene complexes of thiophene have been reported earlier. $^{5}$

The addition of 1.5 equivalents of $n$-BuLi for each equivalent of thieno[2,3- $b]$ thiophene was used to optimize the projected yields of the mono- and dilithiated thieno[2,3- $b]$ thiophene, simultaneously obtaining both mono- and biscarbene products from the same reaction mixture. After the formation of the lithiated intermediates they were reacted with 1.5 equivalents of chromium or tungsten hexacarbonyl, and alkylation with excess triethyloxonium salt afforded the target products. Products were purified with column chromatography with an overall yield of $80-90 \%$ of $\mathbf{1 - 4}$, Scheme 1 . The biscarbene complexes of thieno $[2,3-b]$ thiophene $(3,4)$ display greater stability in solution (reactivity towards carbene oxidation) compared to analogous thiophene and linearly arranged thiophene biscarbene complexes. ${ }^{13,14}$

If the above method is performed in a stepwise procedure of lithiations and reactions with the appropriate metal carbonyls, the method allows for the preparation of mixed metal biscarbene complexes. ${ }^{14}$ To illustrate this, the mixed dimetal biscarbene complex 5 [Cr(CO) $\left.)_{5} \mathrm{C}(\mathrm{OEt})\left\{\mathrm{C}_{6} \mathrm{H}_{2} \mathrm{~S}_{2}\right\} \mathrm{C}(\mathrm{OEt}) \mathrm{W}(\mathrm{CO})_{5}\right]$ was prepared. The addition of a single equivalent of both thieno $[2,3-b]$ thiophene and $n$-BuLi was followed by the addition of one equivalent of chromium hexacarbonyl to form the chromium acylate. The reaction was continued by the addition of a second equivalent of $n$-BuLi followed by an equivalent of tungsten hexacarbonyl, forming the heterobimetallic bisacylate. The reaction was completed by alkylating with excess triethyloxonium tetrafluoroborate. After gradient elution on a silica gel column, four products, 1, 2, 3 and 5

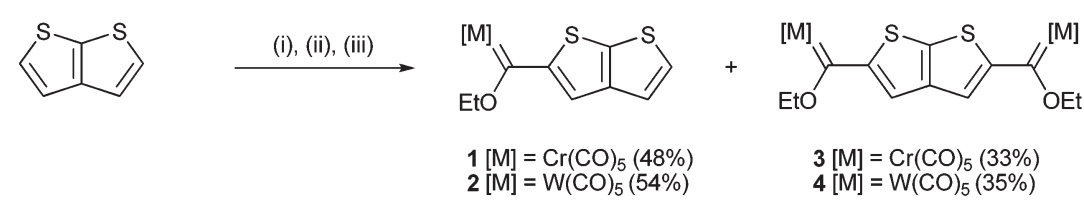

Scheme 1 Synthesis of mono- and biscarbene complexes of thieno[2,3-b]thiophene. (i) 1.5 eq. $n$-BuLi, (ii) 1.5 eq. $\mathrm{Cr}(\mathrm{CO})_{6}$ or W(CO) 6 (iii) excess $\left[\mathrm{Et}_{3} \mathrm{O}\right]\left[\mathrm{BF}_{4}\right]$. 

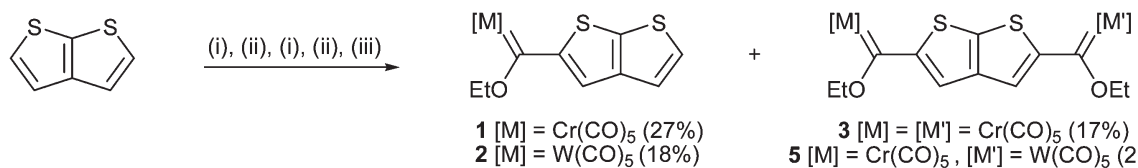

$3[\mathrm{M}]=\left[\mathrm{M}^{\prime}\right]=\mathrm{Cr}(\mathrm{CO})_{5}(17 \%)$

$2[\mathrm{M}]=\mathrm{W}(\mathrm{CO})_{5}(18 \%)$

$5[\mathrm{M}]=\mathrm{Cr}(\mathrm{CO})_{5},\left[\mathrm{M}^{\prime}\right]=\mathrm{W}(\mathrm{CO})_{5}(21 \%)$

Scheme 2 Synthesis of a mixed metal biscarbene complex of thieno[2,3-b]thiophene. (i) 1 eq. $n$-BuLi, (ii) 1 eq. $M(C O)_{6}$ or $M^{\prime}(C O)_{6}$, (iii) excess $\left[\mathrm{Et}_{3} \mathrm{O}\right]\left[\mathrm{BF}_{4}\right]$.

(Scheme 2), were isolated. The outcome of the reaction was only moderately successful with the desired mixed dimetal biscarbene complex representing only a quarter of the products in the reaction mixture. The simultaneous formation of some dilithiated species during the first lithiation step and reaction with a metal carbonyl resulted in homogenous metal carbene formation. The main product, after the first lithiation and reaction with the chromium hexacarbonyl, was the monochromium acylate along with a significant portion of the 5,5'-bisacyldichromate. In addition, the monocarbene of tungsten carbonyl also formed and indicated that a portion of the thieno[2,3-b]thiophene was not lithiated during the initial reaction with $n$-BuLi. The absence of ditungsten biscarbene complex 4 confirmed that an excess of $n$-BuLi was not used during the second lithiation. Nevertheless, the stepwise acylate-formation method was successful in producing a workable yield of the heterobimetallic Fischer biscarbene complex 5. Compounds $\mathbf{1}$ and $\mathbf{2}$ were purified by column chromatography and crystallization, while $\mathbf{3}$ and $\mathbf{5}$ were collected as one fraction and co-crystallize from a dichloromethane-hexane mixture.

The scope of Fischer carbene synthesis is highlighted when the characteristics of lithium-hydrogen (deprotonation) and lithium-halogen exchange reactions are carefully combined and exploited to selectively target lithiations at specific sites on the thiophene substrates. The formation and chelation of biscarbene ligands require the second lithiation to occur at an adjacent, normally less reactive, site on the thiophene ring. Hence, activating the less reactive $\beta$-positions by a favoured lithium-halogen exchange reaction is feasible. The trick for preparing such chelated carbene complexes on a thiophene ring is not to prepare the unstable 1,2-dianion, but to sequentially produce an anion which forms the first metal acylate and can immediately stabilize the formation of the second anion. The synthesis of 6 and 7 is optimized by reacting 3-bromothiophene with one equivalent lithium diisopropylamine (LDA). LDA favours deprotonation at the 2-position of thiophene and leaves the bromo-substituent unaffected in the 3-position. As a result, this will generate the key intermediate 3-bromo-2lithiothiophene (D); the ideal precursor for generating two adjacent reaction positions. Reacting $\mathbf{D}$ with a metal hexacarbonyl results in the metal acylate with the negative charge delocalized over the metal carbonyl moiety. The acylate is subsequently converted into a 2,3-metallocyclic bisacylate intermediate through the addition of an equivalent of $n$-BuLi. Alkylation with excess $\left[\mathrm{Et}_{3} \mathrm{O}\right]\left[\mathrm{BF}_{4}\right]$ affords 6 and 7 in moderate yields (Scheme 3a). Intermediate $\mathbf{D}$ is also accessible using $n$-BuLi instead of LDA, but in lower yields. In this instance a lithium-bromine exchange reaction is favoured and gives 3-lithiothiophene which immediately participates in a trans-lithiation reaction with a second 3-bromothiophene, yielding $\mathbf{D}$.

The synthesis of the bischelated tetracarbene complexes $\mathbf{8}$ and 9 was targeted. The most stable position for anion formation is at the most acidic proton in the thiophene's $\alpha$-position. Thus, it is not necessary to remove $\alpha$-bromo-substituents of tetrabromothiophene to form 3,4-dibromothiophene in order to prepare the bischelated tetracarbene complexes of thiophene 8 and 9. Instead, these complexes can be directly prepared from the substrate tetrabromothiophene. The best method was to dilithiate with 2.5 equivalents $n$-BuLi at the $\alpha$-positions and react the lithiated species with two equivalents

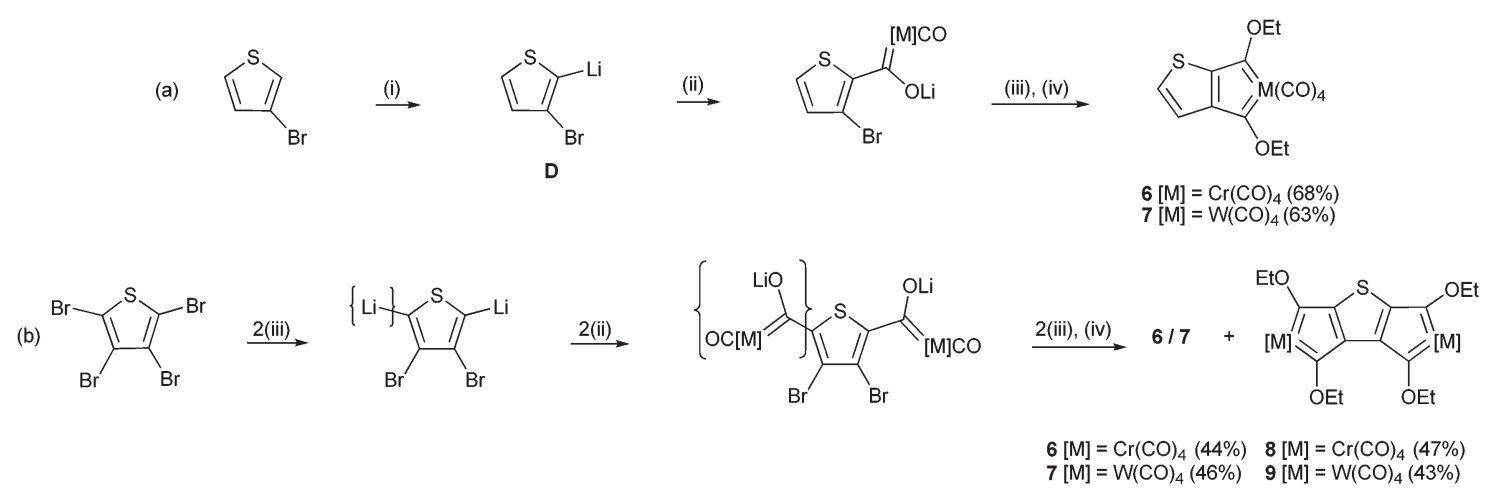

Scheme 3 Synthesis of thiophene chelates from 3-bromothiophene (a) and tetrabromothiophene (b): (i) 1 eq. LDA, (ii) 1 eq. M(CO) 6 , (iii) 1.2 eq. $n$-BuLi and (iv) excess $\left[\mathrm{Et}_{3} \mathrm{O}\right]\left[\mathrm{BF}_{4}\right]$. 
of metal hexacarbonyl to give 2,5-dinuclear bisacylates (Scheme 3b). The acyl charge is delocalized over the metal pentacarbonyl fragments, facilitating the lithium-bromine exchange reaction in the 3- and 4-thiophene positions on addition of a second portion of 2.5 equivalents $n$-BuLi. Intramolecular reactions with a second carbonyl ligand on each of the metal pentacarbonyl units on either side of the thiophene ring resulted in the formation of two bisacylate chelate rings. Alkylation with excess $\left[\mathrm{Et}_{3} \mathrm{O}\right]\left[\mathrm{BF}_{4}\right]$ afforded the dichelated tetraethoxycarbene complexes $(\mathbf{8}, \mathbf{9})$. Similarly, the precursor 4,4'dibromo-thieno[2,3- $b]$ thiophene was considered a suitable substrate to extend the thiophene work to the fused thieno $[2,3-b]$ thiophene system, as it would require the combination of deprotonation (5- and 5'-positions) and lithium-halogen exchange reactions (4- and $4^{\prime}$-positions). However, the synthesis of $4,4^{\prime}$-dibromothieno[2,3-b]thiophene requires the initial formation of $4,4^{\prime}, 5,5^{\prime}$-tetrabromothieno[2,3- $\left.b\right]$ thiophene, followed by the debromination of the 5 - and $5^{\prime}$-positions. ${ }^{11,15}$ Thus, as the thiophene results indicated that it was possible to obtain both mono- and bischelated carbene complexes from the tetrabromothiophene precursor, 4,4',5,5'-tetrabromothieno $[2,3-b]$ thiophene was chosen as substrate to target the formation of both classes of chelated complexes $(10,11,14$ and 15). The reaction of $4,4^{\prime}, 5,5^{\prime}$-tetrabromothieno[2,3- $\left.b\right]$ thiophene with 2.4 equivalents of $n$-BuLi, 2 equivalents of metal carbonyl and another addition of 2.4 equivalents $n$-BuLi, afforded a number of carbene complexes. In Scheme 4 the products isolated and their yields are indicated. They are $\left[\mathrm{M}(\mathrm{CO})_{5}\{\mathrm{C}(\mathrm{OEt})-\right.$ $\left.\left.\mathrm{C}_{6} \mathrm{H}_{2} \mathrm{~S}_{2} \mathrm{C}(\mathrm{OEt})\right\} \mathrm{M}(\mathrm{CO})_{5}\right](\mathrm{M}=\mathrm{Cr} 3, \mathrm{~W} 4),\left[\mathrm{M}(\mathrm{CO})_{4}\{\mathrm{C}(\mathrm{OEt})\}_{2^{-}}\right.$ $\left.\mathrm{C}_{6} \mathrm{H}_{1} \mathrm{~S}_{2} \mathrm{C}(\mathrm{OEt}) \mathrm{M}(\mathrm{CO})_{5}\right](\mathrm{M}=\mathrm{Cr} 12, \mathrm{~W} 13)$ and $\left[\mathrm{M}(\mathrm{CO})_{4}\{\mathrm{C}(\mathrm{OEt})\}_{2^{-}}\right.$ $\left.\mathrm{C}_{6} \mathrm{~S}_{2}\{\mathrm{C}(\mathrm{OEt})\}_{2} \mathrm{M}(\mathrm{CO})_{4}\right](\mathrm{M}=\mathrm{Cr} 14 ; \mathrm{W} 15)$ and trace amounts of $\left[\mathrm{M}(\mathrm{CO})_{4}\{\mathrm{C}(\mathrm{OEt})\}_{2} \mathrm{C}_{6} \mathrm{H}_{2} \mathrm{~S}_{2}\right],(\mathrm{M}=\mathrm{Cr} \mathbf{1 0}, \mathrm{W} 11)$.

The first lithiation occurs at an $\alpha$-position and the second at the other $\alpha$-position. If no further lithium reagent was used after reaction with the metal carbonyl and alkylation, the resulting reaction products were the dinuclear biscarbene complex of the particular metal used $(3,4)$. The formation of biscarbene complexes 3, 4, 10 and 11, in very low yields, provides evidence of incomplete lithiations. The addition of a further 2.4 equivalents of $n$-BuLi yielded the desired bischelated tetra-acylates, which result in the bischelated neutral tetracarbene complexes $\mathbf{1 4}$ and $\mathbf{1 5}$ after alkylation. Incomplete lithiation during the second lithiation step results in the precursor intermediates for the unique complexes $\mathbf{1 2}$ and $\mathbf{1 3 .}$ These complexes never formed in the corresponding reaction with tetrabromothiophene. The greater stability of thieno[2,3b] thiophene tris-acylate intermediates, comparable to isolated mono-acylates, is ascribed to a lack of inter-ring delocalization. Alkylation of the reaction mixture with a large excess $\left[\mathrm{Et}_{3} \mathrm{O}\right]$ $\left[\mathrm{BF}_{4}\right]$ affords the desired bischelated tetracarbene complexes 14 and 15 as well as 12 and 13, in significant yields. The Fischer carbene complexes $\mathbf{1 2}$ and $\mathbf{1 3}$ are without precedent in literature and represent the combination of two different classes of carbene ligands (monocarbene and chelated biscarbene on opposite sides of the thieno[2,3- $b]$ thiophene). A large excess of alkylating agent has been implicated experimentally to play a role in the removal of remaining bromines from intermediates. ${ }^{16}$ The formation of $\mathbf{1 0}$ and 11, in low yields, indicates a lithium-halogen exchange reaction at a less favoured reaction site (4-position) while a more reactive site ( 5 '-position) was still available and remained unaffected. The chelated biscarbene complexes are relatively stable, although flash chromatographic methods were employed for separation.

\section{Spectroscopic characterization}

In the ${ }^{1} \mathrm{H}$ NMR spectra of $\mathbf{1 - 5}, 12$ and 13, the $\mathrm{H} 4$ chemical shift of thieno[2,3-b]thiophene is most affected by the adjacent substitution of $\mathrm{H} 5$ with an electron-withdrawing carbene carbon. A significant downfield shift is observed, compared to the $\alpha$ - and $\beta$-proton chemical shifts of thieno $[2,3-b]$ thiophene at 7.38 and $7.27 \mathrm{ppm}$, respectively (remeasured in $\mathrm{CDCl}_{3}$ ). ${ }^{17}$ The proton chemical shifts of the thiophene ring furthest from the carbene carbon in $\mathbf{1}$ and $\mathbf{2}$ are little affected compared to those of the thieno[2,3- $b]$ thiophene substrate, indicating little inter-ring delocalization. In the monochelated biscarbene complex 10 and 11 only a small downfield shift is observed for both remaining ring protons (Cr: 7.45 and $7.39 \mathrm{ppm}$ and $\mathrm{W}$ : 7.49 and $7.45 \mathrm{ppm}$ ). The corresponding chemical shifts of the<smiles>Brc1sc2sc(Br)c(Br)c2c1Br</smiles>

(i), (ii), (i), (iii)

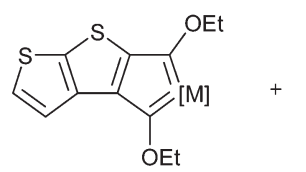

$10[\mathrm{M}]=\mathrm{Cr}(\mathrm{CO})_{4}($ Trace amounts $)$ $11[\mathrm{M}]=\mathrm{W}(\mathrm{CO})_{4}(1 \%)$

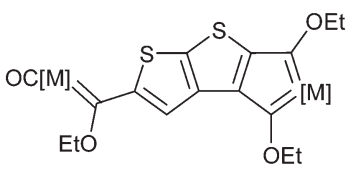

$12[\mathrm{M}]=\mathrm{Cr}(\mathrm{CO})_{4}(23 \%)$ $13[\mathrm{M}]=\mathrm{W}(\mathrm{CO})_{4}(19 \%)$

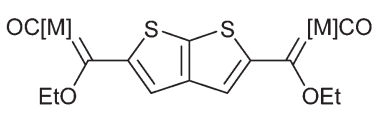

$3[\mathrm{M}]=\mathrm{Cr}(\mathrm{CO})_{4}(3 \%)$ $4[\mathrm{M}]=\mathrm{W}(\mathrm{CO})_{4}(4 \%)$

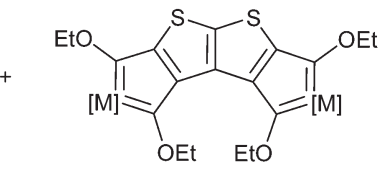

$14[\mathrm{M}]=\mathrm{Cr}(\mathrm{CO})_{4}(41 \%)$ $15[\mathrm{M}]=\mathrm{W}(\mathrm{CO})_{4}(43 \%)$

Scheme 4 Synthesis of chelated biscarbene complexes: (i) 2.4 eq. $n$-BuLi, (ii) 2 eq. $\mathrm{Cr}(\mathrm{CO})_{6}$ or W(CO) ${ }_{6}$ (iii) excess $\left[\mathrm{Et}_{3} \mathrm{O}\right]\left[\mathrm{BF}_{4}\right]$. 
$\alpha$-protons are further downfield (Cr 7.56 and $\mathrm{W} 7.60 \mathrm{ppm}$ ) and the $\beta$-protons slightly upfield ( $\mathrm{Cr} 6.84$ and $\mathrm{W} 6.92 \mathrm{ppm}$ ) in 6 and 7 compared to the corresponding shifts of thiophene at 7.20 and 6.96 ppm, respectively. ${ }^{18}$ The $\mathrm{H} 4$ chemical shifts of the biscarbene complexes $\mathbf{3}$ and $\mathbf{4}$ are slightly more downfield, because of the effect of two versus one electron-withdrawing Fischer carbene carbon, compared to that for $\mathbf{1}$ and 2. The furthest downfield thieno[2,3-b]thiophene chemical shifts of H4 are found for 12 (8.61 ppm) and 13 (8.59 ppm, Fig. 2). Interestingly the chemical shifts of the protons in the 4- and 5 -positions of both thiophene and thieno[2,3- $b]$ thiophene are little affected by the presence of a fused metallocyclic biscarbene chelate ring on the opposite side of the thiophene $\operatorname{ring}(\mathrm{s})$ in 6, 7, 10 and 11. The downfield shifts of the methylene protons of the ethoxycarbene substituents are very sensitive to changes in the electronic properties of the carbene carbon atom. The metal-sensitive methylene resonances of $\mathrm{Cr}$ complexes are shifted downfield by $c a$. 0.2 ppm compared to their $\mathrm{W}$ analogues. The ${ }^{1} \mathrm{H}$ NMR spectrum of 5 represents a combination of the spectra of 3 and $\mathbf{4}$ with almost identical chemical shifts and emphasizes the individuality of each thiophene ring in $\mathbf{5}$.

The ${ }^{1} \mathrm{H}$ NMR spectrum of the triscarbene complex 13, shown in Fig. 2a, displays the characteristic features of mono-, bis- and chelated multicarbene complex-types representative of all complexes in this study. All three carbene ligands are unique and resonate in different chemical environments. The same patterns and trends of chemical shifts of the protons, for the different metals, are observed for the chelated biscarbene analogues (6-15). The methylene protons of the mono- and biscarbene complexes with thienyl substituents resonate around 5.2-5.0 ppm, while the same chemical shifts in the chelated carbene complexes are shifted significantly upfield (around 4.5-4.8 ppm). The latter now falls within the region normally associated with methylene resonances of ester groups. The shifts indicate a smaller involvement of the ethoxy group in stabilizing the carbene carbon, highlighting the role of both the annulated thiophene ring and the attached metallocycles in stabilizing the biscarbene ligands of the chelate ring. Based on resonance structures (Fig. 3) and observations reported for chelated biscarbene complexes of thiophene, assignments were made with the more downfield chemical shift belonging to the ethoxy substituent of the carbene with its carbon furthest from the sulfur atom in the thiophene ring.

The ${ }^{13} \mathrm{C}$ NMR chemical shifts of the carbene and carbonyl carbons as well as the carbon ipso to the carbene carbon are summarized in Table 1. Measurements in $\mathrm{C}_{6} \mathrm{D}_{6}$ give chemical shifts upfield compared to those measured in $\mathrm{CDCl}_{3}$. Fig. $2 \mathrm{~b}$ shows the ${ }^{13} \mathrm{C}$ NMR spectrum of $\mathbf{1 3}$ which is representative of chemical shifts found for the mono-, bis- and chelated biscarbene complexes and divides the spectrum into different chemical shift regions. The chemical shifts of the carbene carbons are metal sensitive with the chromium monocarbene carbons (301-319 ppm) further downfield than the corres-

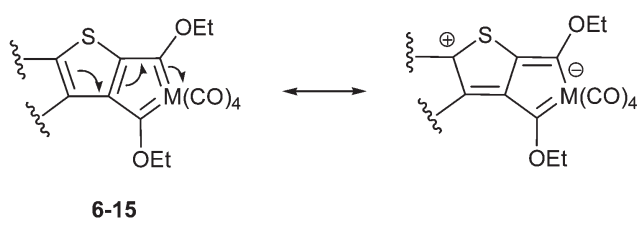

Fig. 3 Electron delocalization from the adjacent thiophene ring, through $\pi$-resonance effects, affecting the carbene ligands in the chelate ring. (a)

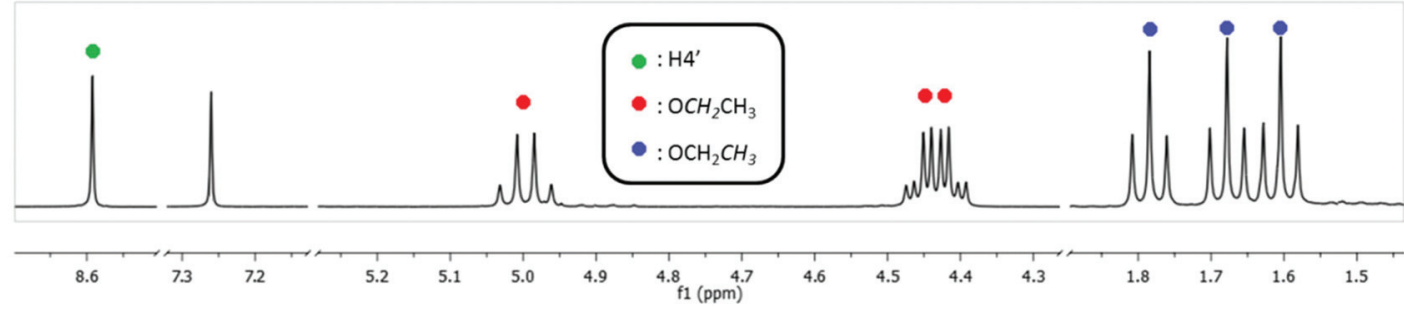

(b)

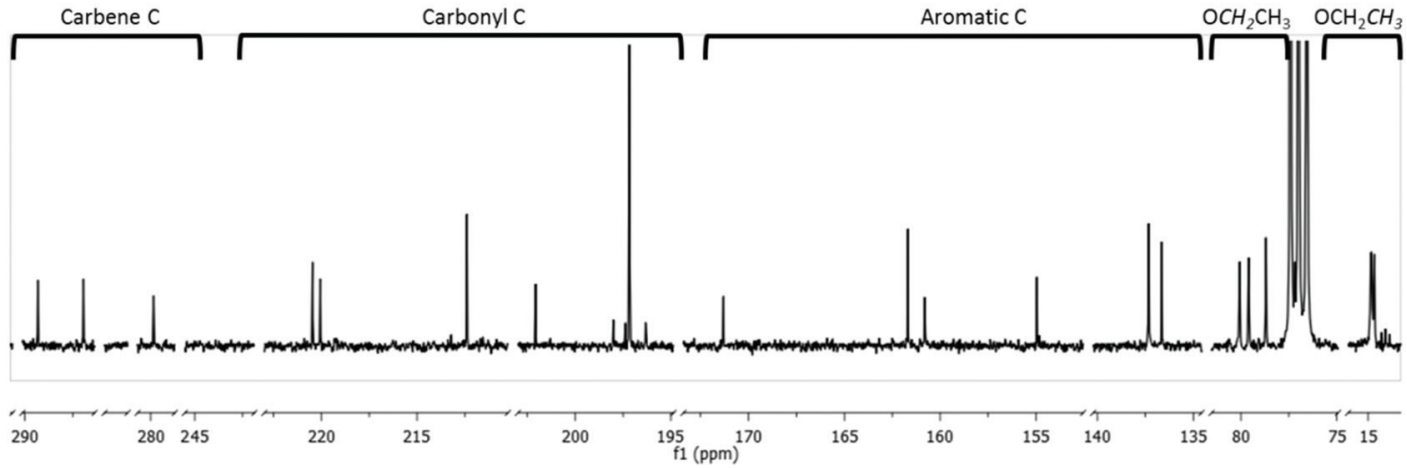

Fig. 2 The ${ }^{1} \mathrm{H}$ NMR (a) and ${ }^{13} \mathrm{C}$ NMR (b) spectra $\left(\mathrm{CDCl}_{3}\right)$ of 13 displaying the chemical shifts of the three electronically different carbene ligands. 
Table 1 Selected downfield ${ }^{13} \mathrm{C}$ NMR chemical shifts ( $p p m$, in solvent $\mathrm{CDCl}_{3}$ ) of the complexes 1-15

\begin{tabular}{|c|c|c|c|c|c|c|}
\hline Complex & $\mathrm{C}_{\mathrm{carb}}^{b}$ & \multicolumn{2}{|l|}{$\mathrm{M}(\mathrm{CO})_{5}$} & \multicolumn{2}{|l|}{$\mathrm{M}(\mathrm{CO})_{4}$} & $\mathrm{C}_{i p s o}$ \\
\hline 2 & 288.3 & 202.3 & 197.6 & & & 160.6 \\
\hline 3 & 315.3 & 223.0 & 216.8 & & & 158.2 \\
\hline 4 & 289.5 & 202.2 & 197.3 & & & 161.7 \\
\hline $5(\mathrm{Cr})$ & 315.5 & 223.1 & 216.8 & & & 158.3 \\
\hline $7^{c}$ & $313.9,283.3$ & & & n.o., 201.1 & 191.1 & 164.7, n.o. \\
\hline 8 & $316.5,301.7$ & & & $245.5,239.5$ & 226.0 & $165.0,151.6$ \\
\hline $9^{c}$ & $317.8,283.7$ & & & $212.4,209.1$ & 194.8 & $165.4,158.3$ \\
\hline 11 & $289.3,281.8$ & & & $220.4,220.2$ & 212.4 & $171.4,160.2$ \\
\hline \multirow[t]{2}{*}{12} & $314.9,307.2$ & & & $243.8,243.5$ & 228.1 & $158.6,156.9$ \\
\hline & 315.1 & 223.0 & 216.7 & & & 164.4 \\
\hline 13 & $286.9,279.8$ & & & $220.5,220.1$ & 212.4 & $161.7,160.8$ \\
\hline
\end{tabular}

ponding tungsten complexes (280-294 ppm). The carbonyl carbon chemical shifts for $\mathrm{M}(\mathrm{CO})_{5}$ are around 223 (trans) and $217 \mathrm{ppm}$ (cis) for chromium while the tungsten shifts are around 202 (trans) and $197 \mathrm{ppm}$ (cis). The metal tetracarbonyl fragments display three peaks in the ${ }^{13} \mathrm{C}$ NMR spectra and the chemical shifts are found more downfield than those of the pentacarbonyl moieties. The two smaller peaks furthest downfield in the carbonyl region represent the carbonyl ligands trans to the two carbene carbons, indicating that they resonate in different electronic environments. The larger peak less downfield represents the two cis carbonyl ligands, which are trans to each other. The chemical shift values for the metal carbonyl moieties are characteristic of a specific metal and the difference in chemical shift values of the carbonyl resonances is approximately $20 \mathrm{ppm}$ for the chromium and tungsten complexes. The resonances of the ipso-carbons attached to carbene carbons are very similar, with the tungsten carbene complexes being shifted slightly further downfield compared to the corresponding chromium carbene complexes.

The number, pattern and positions of the infrared bands in the carbonyl region of the infrared spectra confirm the presence of $\mathrm{M}(\mathrm{CO})_{5}$ fragments in $\mathbf{1 - 5}$ and $\mathbf{1 2}, 13$ and cis-M(CO) fragments in $\mathbf{6}-15 .{ }^{19}$ Characteristic of the biscarbene complexes $(3,4$ and 5$)$ is the duplication of the $\mathrm{A}_{1}{ }^{(1)}$ band (Fig. 4), the reason speculatively ascribed to the existence of two different orientated vibrational modes for the two equatorial planes of cis-carbonyl ligands in the complexes. The IR spectrum of the tungsten complex 4 displayed higher wavenumbers for the $\mathrm{A}_{1}^{(1)}$ band compared to the chromium analogue 3 , but this order is reversed for the vibrational frequencies at lower wavenumbers $\left(\mathrm{A}_{1}{ }^{(2)}\right.$ and $\mathrm{E}$ modes). The vibrational frequencies of 5 fall between the values of $\mathbf{3}$ and $\mathbf{4}$. Complexes $\mathbf{1 2}$ and $\mathbf{1 3}$ contain both cis-tetra- and pentacarbonyl fragments. The $\mathrm{A}_{1}{ }^{(2)}$ and $\mathrm{E}$ carbonyl stretching vibrational modes of the $\mathrm{M}(\mathrm{CO})_{5}$

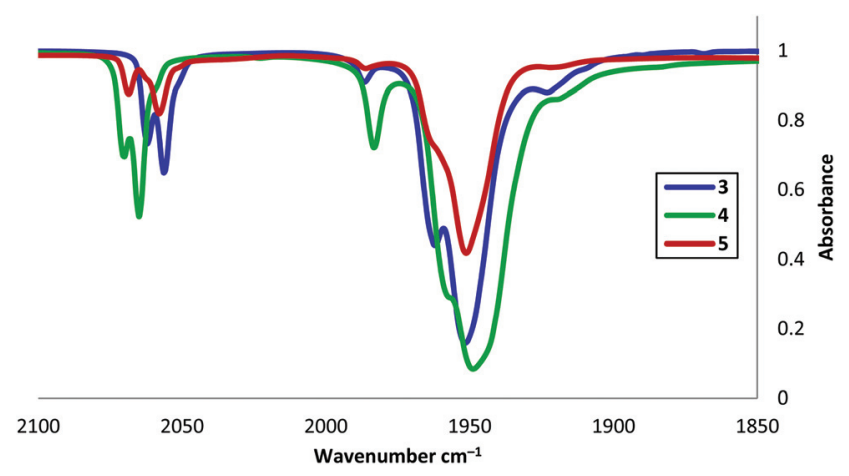

Fig. 4 Comparison of the $v_{\mathrm{CO}}$ bands displayed by 3, 4 and 5 .

fragment overlap with the $\mathrm{B}_{1}$ mode of the cis- $\mathrm{M}(\mathrm{CO})_{4}$ fragment of 13, resulting in poor resolution that complicates assignments.

\section{Structural studies of the carbene complexes}

The molecular structures of 2, 4, 5, 7, 13 and 15 (Fig. 5-8) were studied by single crystal X-ray diffraction analyses. The crystal structures display a planar thiophene or thieno[2,3-b]thiophene moiety attached to a metal carbonyl fragment and an ethoxycarbene substituent. In $\mathbf{5}$, the crystal structure refinement indicated $68 \%$ chromium and $32 \%$ tungsten at one metal location (Cr1/W1) and $70 \%$ chromium and $30 \%$ tungsten at the other metal location $(\mathrm{Cr} 2 / \mathrm{W} 2)$. This means that 3 co-crystallized with 5 in a ratio of $38: 62$ and was confirmed by peak integration in the ${ }^{1} \mathrm{H}$ NMR spectrum of 5 . The mono- and biscarbene complexes (1-5) all have the ethoxy substituent on the same side of the adjacent thiophene sulfur atom, while the orientation of the ethoxy substituents in 6-15 are determined by the rigidity of the chelate rings. 

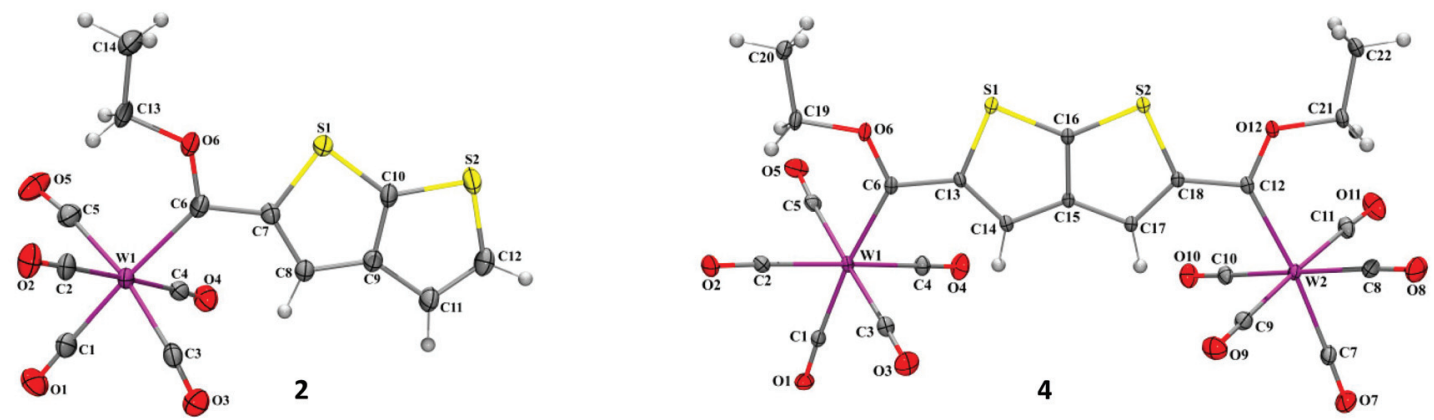

Fig. 5 Molecular structure representation of 2 and 4 (thermal ellipsoids are shown with $50 \%$ probability).

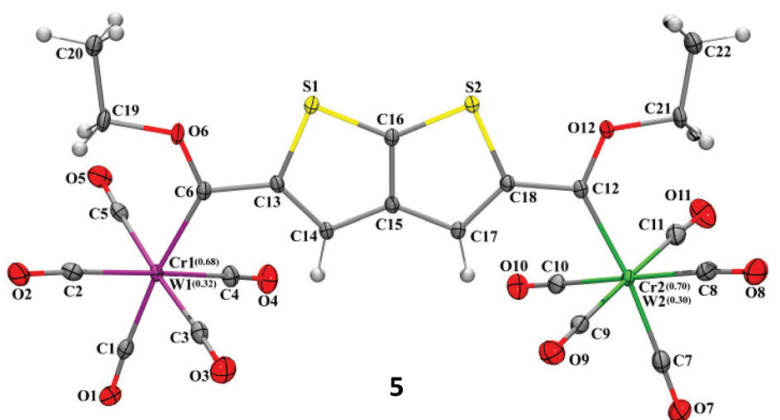

Fig. 6 Molecular structure representations of 5 (thermal ellipsoids are shown with $50 \%$ probability).

In the molecular structures, one linear pair of the cis-pentacarbonyl ligands usually bend away from the carbene. By contrast, the pair of cis-tetracarbonyl ligands, perpendicular to the chelate ring, bend towards the chelate ring. For the mono- and biscarbene complexes (2, 4 and 5) as well as 13, only one pair of the cis-pentacarbonyl ligands, per complex, were shown to bend away significantly. For 2 this deviation from linear is $-9.2(1)^{\circ}$, while the greatest deviations in $\mathbf{4}$ and 5 are $c a .-7 \circ$. In the tetracarbonyl complexes the greatest deviations of the cis-carbonyl ligands are in $15\left(7.7(1)^{\circ}\right.$ and $5.6(1)^{\circ}$ respectively).

The inter-ring torsion angles of thieno[2,3- $b]$ thiophene confirm that the planarity of the thieno[2,3-b]thiophene linker is retained in the structures, irrespective of the number of metal moieties in the carbene complexes. All structures display only small deviations from planarity for the condensed thieno $[2,3-b]$ thiophene ring with the carbene carbons and the torsion angles $\left(\mathrm{C}_{\text {carb }}-\mathrm{C}_{\text {ipso }}-\mathrm{C}_{\beta}-\mathrm{C} 9 / 15\right.$ and $\mathrm{C}_{\text {carb }}-\mathrm{C}_{\text {ipso }}-\mathrm{C} 9 / 15-$ C10/16) deviate with less than $7^{\circ}$, with the exception of $\mathbf{1 5}$. With only one ethoxy substituent in 13, on the opposite side of the sulfur atoms, the steric repulsion in this part of the molecule is far less compared to that in 15. As a result, the threering linker in $\mathbf{1 3}$ deviates less from planarity compared to the four rings in 15. This deviation from the backbone is the result of steric constraints caused by the metal tetracarbonyl and ethoxy fragments. The torsion angles also indicate that the ethoxy groups of $\mathbf{1 5}$ (especially on the opposite side of the sulfur atoms) are bent out of the mean plane, in order to alleviate the steric congestion and retain ring planarity as far as possible (Fig. 9). The distortion in this part of the molecule is illustrated by the short non-bonding distance between $\mathrm{O} 6$ and $\mathrm{O} 12(2.693 \AA)$ and the torsion angle $\mathrm{O} 12 \cdots \mathrm{C} 18 \cdots \mathrm{C} 14 \cdots \mathrm{O} 6$ $\left(-45.65^{\circ}\right)$. This effect of the close proximity of the two nonbonded oxygens atoms in 15, forces the C6 and C12 carbene carbons out of the ring plane $\left(17.3(2)^{\circ}\right.$ and $16.6(2)^{\circ}$, below and above respectively).

The $\mathrm{W}-\mathrm{C}_{\text {carb }}$ bond length in 2 (2.214(3) $\AA$ ) is slightly longer that those in 4 (averaged 2.197(3) $\AA$ ) and the analogous thiophene biscarbene complex (averaged 2.191(5) ̊). ${ }^{5 b}$ The significantly shorter $\mathrm{W}-\mathrm{C}_{\text {carb }}$ bond distances of the chelate rings are
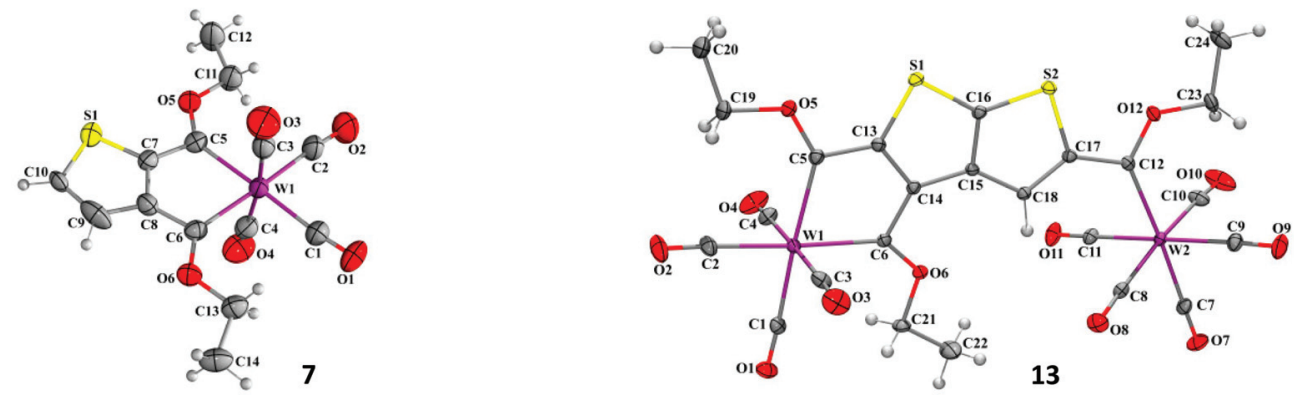

Fig. 7 Molecular structures of 7 and 13 (thermal ellipsoids are shown with 50\% probability). The DCM molecule, per two molecules of 13 , is not shown for simplicity. 


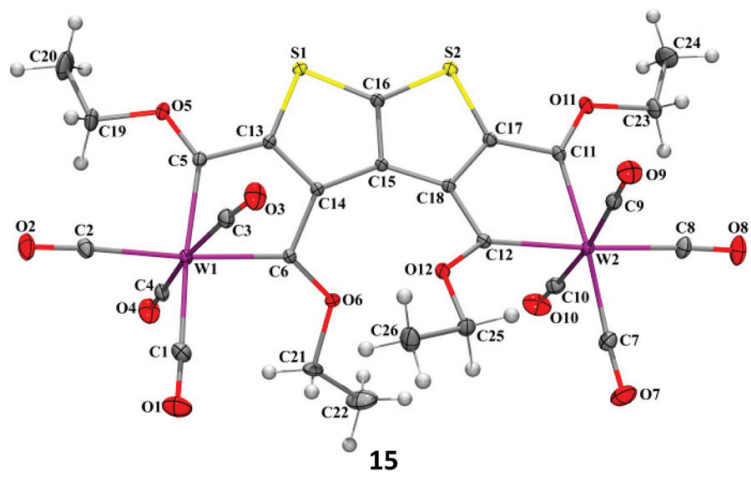

Fig. 8 Molecular structure representation of 15 (thermal ellipsoids are shown with $50 \%$ probability).

ascribed to restrictions imposed by the ring size and electronic effects resulting from chelation. The role of ring strain is further emphasized by a small decrease in the $\mathrm{W}-\mathrm{C}_{\text {carb }}$ bond distances on going from $\mathbf{1 3}$ to $\mathbf{1 5}$ as well as a shorter C-S distance $\left(\mathrm{S} 2-\mathrm{C}_{\text {out }}\right)$ in the thienothiophene unit when adjacent to a chelate biscarbene ring. The chelate rings affect the geometry around the carbene carbons of $\mathbf{1 3}$ and 15. This manifests in a smaller $\mathrm{W}-\mathrm{C}_{\mathrm{carb}}-\mathrm{C}$ angle compared to the corresponding angles in 2, 4 and 5, and a noticeable increase in the angle between the tungsten pentacarbonyl and the ethoxy moiety of the chelated carbene carbons. For the thieno[2,3- $b]$ thiophene linker, the $\mathrm{C}-\mathrm{C}$ bond lengths show consecutive shorter-longer bond distances, retaining single and double bond character of the uncoordinated thieno[2,3- $b]$ thiophene fragment. For comparison, the $\mathrm{C}-\mathrm{C}$ bond distances in 4,4-dibromothieno[2,3- $b]$ thiophene are 1.358(8), 1.429(7) and 1.374(7) (internal). ${ }^{11}$ The $\mathrm{C}-\mathrm{C}$ bond common to both the chelate and the thiophene rings, have similar distances for 7, 13 and 15 (Table 2).

\section{Crystal packing properties of 5, 7, 13 and 15}

The packing of 5, 7, 13 and $\mathbf{1 5}$ varies from grid-like networks (Fig. 10a and b (5 and 7)), to "wheels" (Fig. 10c (13)) to parallel corrugated lines (Fig. 10d (15)), maintained at least in part by intermolecular hydrogen interactions. These intermolecular hydrogen interactions $(\mathrm{O} \cdots \mathrm{H})$ occur predominantly between the oxygen of the carbonyl ligand and a hydrogen on the methylene or methyl group. The hydrogen interactions range from 2.430 to $2.712 \AA$. No $\pi$-stacking interaction of the (thieno)- thiophene rings was observed, with the shortest distance between any of the rings being larger than 4 A. Compounds 4 and 5 pack in a similar fashion, with the same intermolecular interactions. The complexes undergo columnar packing when viewed down two different axes respectively, with the molecules fitting on top of each other down the column. This basic structural motif (columns) can be divided into different levels of crystal organization, primary (columns) and secondary (layers of columns). ${ }^{20}$ The packing of 5, viewed down the crystallographic $a$-axis, shows columns that are parallel-packed together in an interlocked non-planar fashion. The thiophene rings stack in the crystal structure but without $\pi-\pi$ interaction (separation distance of $13.056 \AA$ ). The formation of a grid-like network is evident from the view along the crystallographic $a$-axis, Fig. 10a, consisting of two dimers that pack antiparallel to each other. In the case of 7 , the grid-like network consists of two dimers that pack parallel to each other and the $\mathrm{O} \cdots \mathrm{H}$ interactions now occur predominantly between the oxygens of carbonyl ligands and the $\alpha$-hydrogen of a thiophene ring or a hydrogen on the methylene or methyl group. (Fig. 10b). The packing of 13, viewed down the crystallographic $c$-axis, consists of columns of "wheels" that pack parallel to each other. Each "wheel" contains two dimers that pack antiparallel to each other, with the four chelated rings facing to the outside, Fig. 10c. Corrugated lines consisting of antiparallel-packed dimers, in the vertical direction, is observed for $\mathbf{1 5}$ when viewed down the crystallographic $c$-axis, Fig. 10d.

\section{Experimental section}

\section{General}

Thiophene, tetrabromothiophene, thieno[2,3-b]thiophene, 1,4-bistrimethylsilyl-1,3-butadiyne, $n$-BuLi (1.6 M solution in hexane), chromium and tungsten hexacarbonyls were purchased from Sigma Aldrich and Strem Chemicals and used as received. Thieno[2,3- $b]$ thiophene can be prepared from trimethylsilyl-1,3-pentadiyne, ${ }^{11}$ while procedures from literature were employed for the preparation of $4,4^{\prime}, 5,5^{\prime}$-tetrabromothieno[2,3- $b]$ thiophene ${ }^{21}$ and triethyloxonium tetrafluoroborate. $^{22}$ All operations were carried out using standard Schlenk techniques under an inert atmosphere of nitrogen or argon. Silica gel 60 (particle size $0.063-0.20 \mathrm{~mm}$ ) was used as resin for all column chromatography separations. Anhydrous THF (tetrahydrofuran) and hexane were distilled over sodium (a)

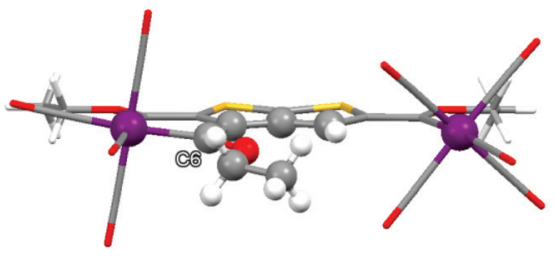

(b)

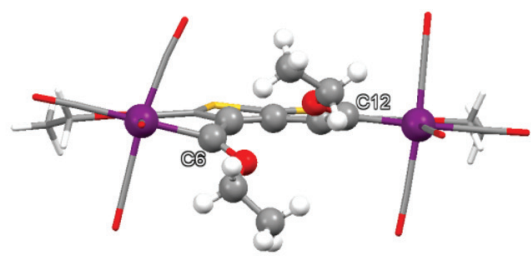

Fig. 9 Orientation of the planar bridging thienothiophene moiety and ethoxycarbene substituents of 13 (a) and 15 (b), viewed parallel with the mean plane through thieno[2,3-b]thiophene. 
Table 2 Selected bond lengths, bond angles and torsion angles for 2, 4, 5, 7, 13 and 15

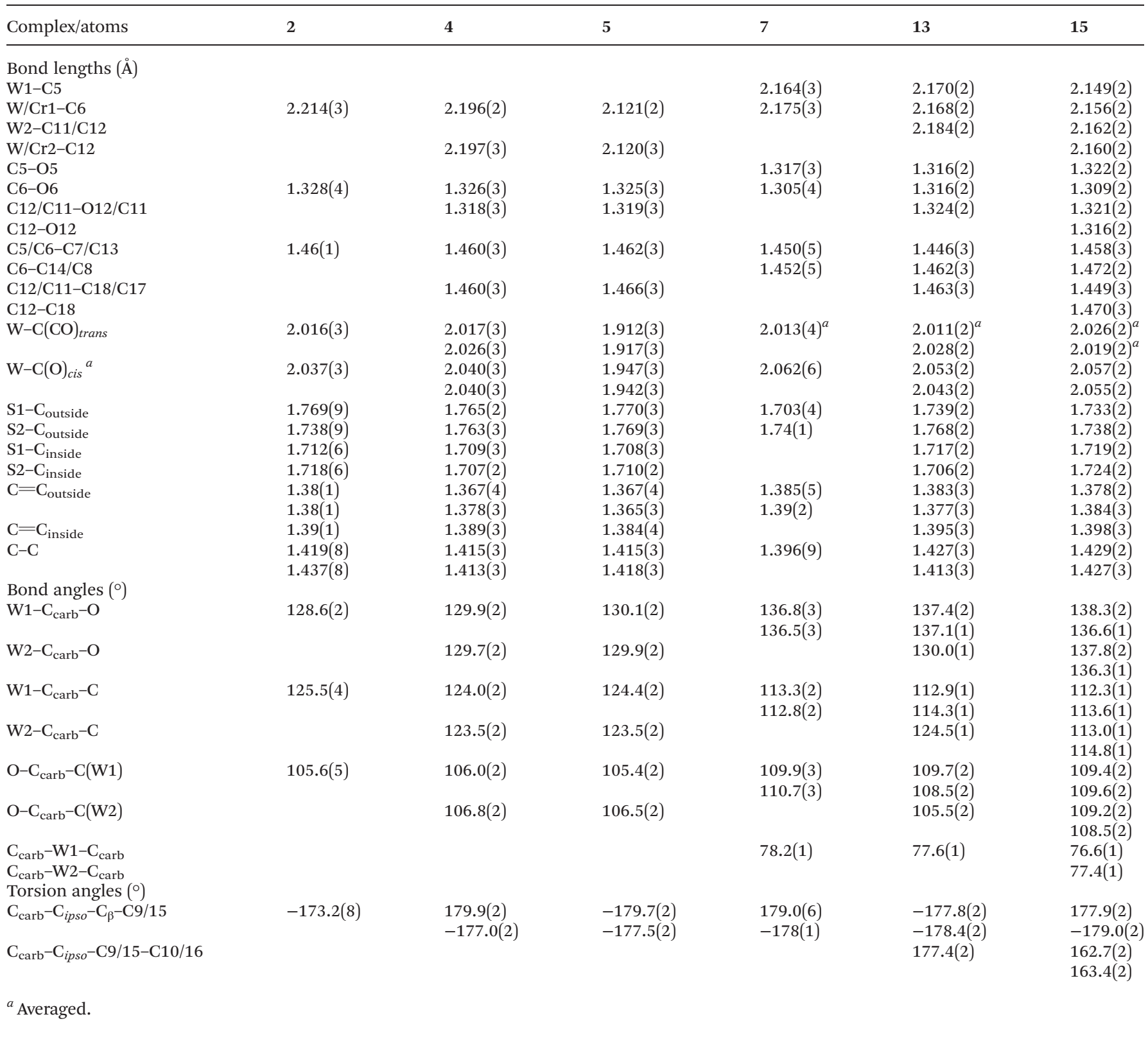

metal and DCM (dichloromethane) over $\mathrm{CaH}_{2}$. NMR spectra were recorded on Bruker ADVANCE 500, Ultrashield Plus 400 AVANCE 3 and Ultrashield 300 AVANCE 3 spectrometers, at $25{ }^{\circ} \mathrm{C}$, using $\mathrm{CDCl}_{3}$ and/or $\mathrm{C}_{6} \mathrm{D}_{6}$ as solvent. The ${ }^{1} \mathrm{H}$ NMR spectra were recorded at $500.139,400.13$ or $300.13 \mathrm{MHz}$, and the ${ }^{13} \mathrm{C}$ NMR spectra at $125.75,100.613$ or $75.468 \mathrm{MHz}$. The chemical shifts were referenced to deuterated chloroform $\left(\mathrm{CDCl}_{3}\right)$ signals at $7.26 \mathrm{ppm}$ for $\delta_{\mathrm{H}}$ and $77.00 \mathrm{ppm}$ for $\delta_{\mathrm{C}}$, or deuterated benzene at $7.16 \mathrm{ppm}$ and $128.00 \mathrm{ppm}$, respectively. Numerical numbering of atoms for NMR spectral assignments is indicated in Fig. 11. Infrared spectroscopy was performed on a Bruker ALPHA FT-IR spectrophotometer with a $\mathrm{NaCl}$ cell, using hexane as solvent. Mass spectral analyses were performed on a Synapt G2 HDMS, by direct infu- sion at $10 \mu \mathrm{L} \min ^{-1}$, with negative electron spray as ionization technique for compounds 1-5 and 11-15. Samples were made up in $100 \% \mathrm{MeOH}$ to an approximate concentration of $10 \mu \mathrm{g} \mathrm{mL}{ }^{-1}$. The $\mathrm{m} / z$ values were measured in the range of 100-1500. Elemental analysis data for 6-9 were obtained from a Thermoscientific Flash 2000 organic elemental analyser.

\section{Crystallography}

Single crystal diffraction data for 2, 4, 5, 13 and 15 were collected at $150 \mathrm{~K}$ on a Bruker D8 Venture diffractometer with a kappa geometry goniometer and a Photon 100 CMOS detector using a Mo-K $\alpha$ I $\mu$ S.micro focus source. Data for 7 were collected at $293 \mathrm{~K}$ on a Siemens $\mathrm{P} 4$ diffractometer fitted with a 
(a)

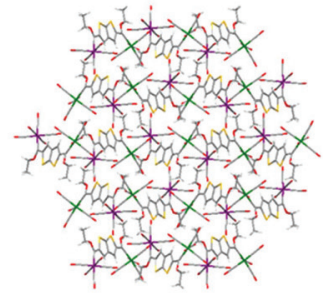

(b)

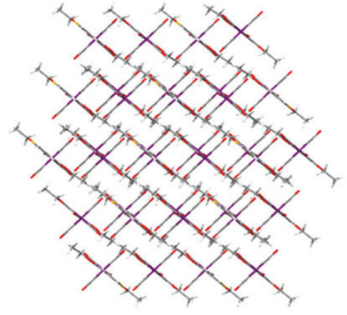

(c)

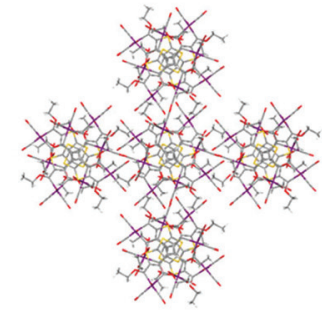

(d)

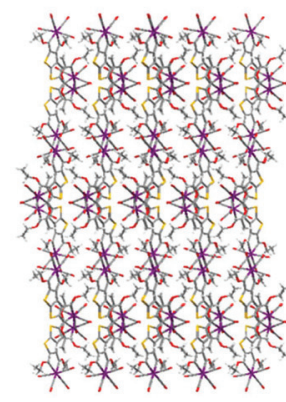

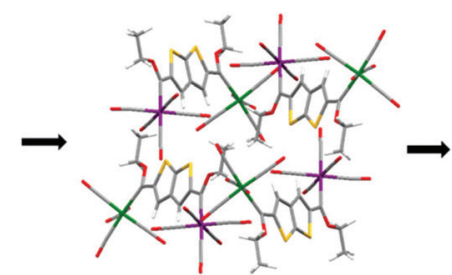
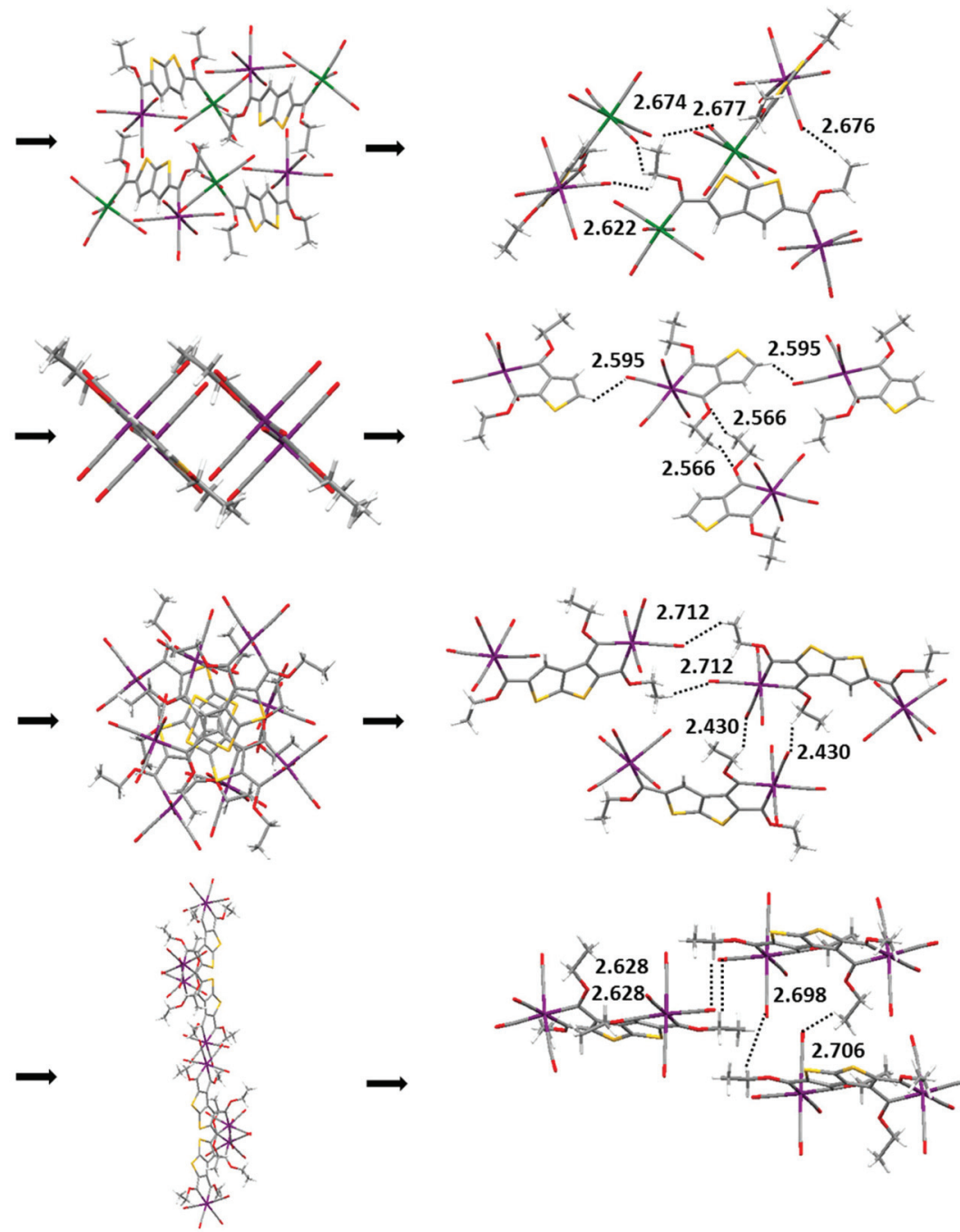

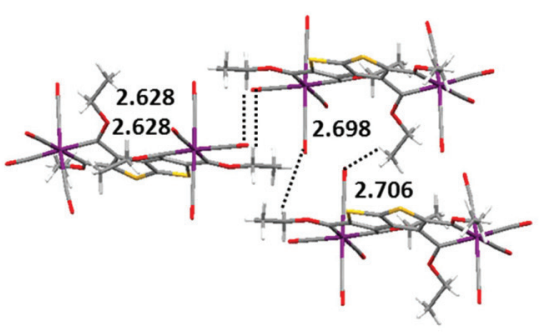

Fig. 10 Packing features of 5 (a) when viewed down the crystallographic a-axis, 7 (b) viewed down the crystallographic $b$-axis, 13 (c) and 15 (d) viewed down the crystallographic c-axis.

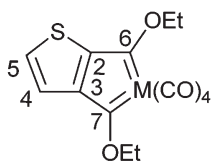<smiles>CCOC(=O)c1cc2ccsc2s1</smiles><smiles>CCOC1=NC(=O)c2c1sc1sccc21</smiles>

Fig. 11 Numerical proton and carbon assignments used for thiophene, thieno[2,3-b]thiophene and carbene substituents.

Bruker SMART $1 \mathrm{~K}$ CCD detector using graphite-monochromated Mo-K $\alpha$ radiation by means of a combination of phi and omega scans. Data were reduced and scaled using SAINT. ${ }^{23}$ Absorption corrections were performed using SADABS. ${ }^{23}$ The structures were solved by a novel duel-space algorithm using SHELXTS $^{24}(2,4,5,13$ and 15) or by direct methods (7) and were refined by full-matrix least-squares methods based on $F^{2}$ using SHELXL. ${ }^{25}$ All non-hydrogen atoms were refined anisotropically. All hydrogen atoms were placed in idealized positions and refined using riding models.
Preparation of thieno[2,3-b]thiophene carbene complexes: $\left[\mathrm{Cr}(\mathrm{CO})_{5} \mathrm{C}(\mathrm{OEt})\left\{\mathrm{C}_{6} \mathrm{H}_{3} \mathrm{~S}_{2}\right\}\right] \quad(1), \quad\left[\mathrm{W}(\mathrm{CO})_{5} \mathrm{C}(\mathrm{OEt})\left\{\mathrm{C}_{6} \mathrm{H}_{3} \mathrm{~S}_{2}\right\}\right] \quad$ (2), $\left[\mathrm{Cr}(\mathrm{CO})_{5} \mathrm{C}(\mathrm{OEt})\left\{\mathrm{C}_{6} \mathrm{H}_{2} \mathrm{~S}_{2}\right\} \mathrm{C}(\mathrm{OEt}) \mathrm{Cr}(\mathrm{CO})_{5}\right] \quad$ (3), [W(CO) $)_{5} \mathrm{C}(\mathrm{OEt})-$ $\left.\left\{\mathbf{C}_{6} \mathbf{H}_{2} \mathbf{S}_{2}\right\} \mathbf{C}(\mathbf{O E t}) \mathbf{W}(\mathbf{C O})_{5}\right]$ (4). A solution of $0.19 \mathrm{~mL}(1.8 \mathrm{mmol})$ of thieno[2,3-b]thiophene in $15.0 \mathrm{~mL}$ of THF was treated with $1.64 \mathrm{~mL}(2.6 \mathrm{mmol})$ of $n$-BuLi at $-78{ }^{\circ} \mathrm{C}$. After stirring for 30 min., $\mathrm{Cr}(\mathrm{CO})_{6}(0.58 \mathrm{~g}, 2.6 \mathrm{mmol})$ or $\mathrm{W}(\mathrm{CO})_{6}(0.93 \mathrm{~g}$, $2.6 \mathrm{mmol}$ ) was added to the solution and stirred for a further $15 \mathrm{~min}$ in the cold and then allowed to reach room temperature over $40 \mathrm{~min}$. The solvent was removed under reduced 
pressure and the residue dissolved in $10 \mathrm{~mL}$ of DCM and cooled to $-20^{\circ} \mathrm{C}$. The reaction mixture was treated with $0.80 \mathrm{~g}$ $(4.0 \mathrm{mmol})$ of $\left[\mathrm{Et}_{3} \mathrm{O}\right]\left[\mathrm{BF}_{4}\right]$ in DCM and subsequently allowed to reach room temperature. The reaction mixture was filtered through a small silica gel plug using DCM and the solvent was removed under reduced pressure. After absorbing the reaction mixture on silica, it was dry loaded onto a silica gel column. The respective products (1-4) were separated by column chromatography using gradient elution with hexane and DCM.

1: Yield: $0.33 \mathrm{~g}$ (0.8 mmol, 48\%), red crystals. ${ }^{1} \mathrm{H}$ NMR $\left(\mathrm{CDCl}_{3}, 300.13 \mathrm{MHz}\right) \delta: 8.41$ (s, 1H, H4), 7.37 (s, 1H, H5'), 7.37 (s, 1H, H4') 5.18 (q, $7.0 \mathrm{~Hz}, 2 \mathrm{H}, \mathrm{CH}_{2}$ ), 1.68 (t, $7.0 \mathrm{~Hz}, 3 \mathrm{H}$, $\left.\mathrm{CH}_{3}\right) .{ }^{13} \mathrm{C} \mathrm{NMR}\left(\mathrm{CDCl}_{3}, 75.468 \mathrm{MHz}\right) \delta$ : $313.6\left(\mathrm{C}_{\text {carb }}\right), 223.1((\mathrm{Cr}-$ $\left.\left.(\mathrm{CO})_{5}\right)_{\text {trans }}\right), 217.1\left(\left(\mathrm{Cr}(\mathrm{CO})_{5}\right)_{\text {cis }}\right), 157.7$ (C5), 134.8 (C4), 147.4 (C3), n.o. (C2), $129.5\left(\mathrm{C5}^{\prime}\right), 121.6\left(\mathrm{C}^{\prime}\right), 75.9\left(\mathrm{CH}_{2}\right), 15.1\left(\mathrm{CH}_{3}\right)$. IR $\left(\mathrm{cm}^{-1}\right.$, hexane, $\left.\nu_{\mathrm{CO}}\right): \mathrm{M}(\mathrm{CO})_{5}: \mathrm{A}_{1}^{(1)} 2058(\mathrm{~m}), \mathrm{B}_{1} 1983$ (vw), $\mathrm{A}_{1}{ }^{(2)} 1957$ (sh), E 1947 (vs). Calc. $\mathrm{C}_{14} \mathrm{H}_{8} \mathrm{O}_{6} \mathrm{~S}_{2} \mathrm{Cr}\left(387.92 \mathrm{~g} \mathrm{~mol}^{-1}\right)$ MS ( $\mathrm{m} / z$, intensity (\%)); $274.89(11 \%)[\mathrm{M}-4 \mathrm{CO}-\mathrm{H}]^{-}$.

2: Yield: $0.49 \mathrm{~g},(0.9 \mathrm{mmol}, 54 \%)$, red crystals. ${ }^{1} \mathrm{H}$ NMR $\left(\mathrm{CDCl}_{3}, 300.13 \mathrm{MHz}\right) \delta: 8.34(\mathrm{~s}, 1 \mathrm{H}, \mathrm{H} 4), 7.39(\mathrm{~d}, 5.3 \mathrm{~Hz}, 1 \mathrm{H}$, H5'), 7.36 (d, $5.3 \mathrm{~Hz}, 1 \mathrm{H}, \mathrm{H} 4^{\prime}$ ), 5.00 (q, $7.1 \mathrm{~Hz}, 2 \mathrm{H}, \mathrm{CH}_{2}$ ), 1.66 $\left(\mathrm{t}, 7.1 \mathrm{~Hz}, 3 \mathrm{H}, \mathrm{CH}_{3}\right) .{ }^{13} \mathrm{C} \mathrm{NMR}\left(\mathrm{CDCl}_{3}, 75.468 \mathrm{MHz}\right) \delta: 288.3$ $\left(\mathrm{C}_{\text {carb }}\right), 202.3\left(\left(\mathrm{~W}(\mathrm{CO})_{5}\right)_{\text {trans }}\right), 197.6\left(\left(\mathrm{~W}(\mathrm{CO})_{5}\right)_{\text {cis }}\right), 160.6$ (C5), 135.7 (C4), 147.3 (C3), 148.2 (C2), 129.8 (C5'), 121.6 (C4'), 78.4 $\left(\mathrm{CH}_{2}\right), 14.9\left(\mathrm{CH}_{3}\right)$. IR $\left(\mathrm{cm}^{-1}\right.$, hexane, $\left.\nu_{\mathrm{CO}}\right): \mathrm{M}(\mathrm{CO})_{5}: \mathrm{A}_{1}^{(1)} 2066$ (m), $\quad \mathrm{B}_{1} 1979$ (vw), $\mathrm{A}_{1}^{(2)} 1952$ (sh), E 1943 (vs). Calc. $\mathrm{C}_{14} \mathrm{H}_{8} \mathrm{O}_{6} \mathrm{~S}_{2} \mathrm{~W}\left(519.93 \mathrm{~g} \mathrm{~mol}^{-1}\right.$ ) MS ( $\mathrm{m} / \mathrm{z}$, intensity (\%)); 564.87 (31\%) $[\mathrm{M}+\mathrm{FA}-\mathrm{H}]^{-}$(FA = formic acid).

3: Yield: $0.37 \mathrm{~g}$ (0.6 mmol, 33\%), purple crystals. ${ }^{1} \mathrm{H}$ NMR $\left(\mathrm{CDCl}_{3}, 300.13 \mathrm{MHz}\right) \delta: 8.47$ (s, 2H, H4), 5.21 (q, $6.5 \mathrm{~Hz}, 4 \mathrm{H}$, $\left.\mathrm{CH}_{2}\right), 1.70\left(\mathrm{t}, 6.6 \mathrm{~Hz}, 6 \mathrm{H}, \mathrm{CH}_{3}\right) .{ }^{13} \mathrm{C} \mathrm{NMR}\left(\mathrm{CDCl}_{3}, 75.468 \mathrm{MHz}\right)$ $\delta: 315.3\left(\mathrm{C}_{\text {carb }}\right), 223.0\left(\left(\mathrm{Cr}(\mathrm{CO})_{5}\right)_{\text {trans }}\right), 216.8\left(\left(\mathrm{Cr}(\mathrm{CO})_{5}\right)_{\text {cis }}\right), 158.2$ (C5), 135.4 (C4), 147.2 (C3), 153.5 (C2), $76.3\left(\mathrm{CH}_{2}\right), 15.2\left(\mathrm{CH}_{3}\right)$. IR $\left(\mathrm{cm}^{-1}\right.$, hexane, $\left.\nu_{\mathrm{CO}}\right): \mathrm{M}(\mathrm{CO})_{5}: \mathrm{A}_{1}{ }^{(1)} 2062$ and $2056(\mathrm{~m})$, $\mathrm{B}_{1} 1986$ (vw), $\mathrm{A}_{1}{ }^{(2)} 1962$ (sh), E 1952 (vs). Calc. $\mathrm{C}_{22} \mathrm{H}_{12} \mathrm{O}_{12} \mathrm{~S}_{2} \mathrm{Cr}_{2}\left(635.86 \mathrm{~g} \mathrm{~mol}{ }^{-1}\right)$ MS $(\mathrm{m} / z$, intensity (\%)); 606.87 (28\%) $[\mathrm{M}-\mathrm{CO}-\mathrm{H}]^{-}$.

4: Yield: $0.55 \mathrm{~g}$ (0.6 mmol, 35\%), purple crystals. ${ }^{1} \mathrm{H}$ NMR $\left(\mathrm{CDCl}_{3}, 300.13 \mathrm{MHz}\right) \delta: 8.39$ (s, 2H, H4), 5.01 (q, $7.1 \mathrm{~Hz}, 4 \mathrm{H}$, $\left.\mathrm{CH}_{2}\right), 1.68$ (t, $\left.7.1 \mathrm{~Hz}, 6 \mathrm{H}, \mathrm{CH}_{3}\right) .{ }^{13} \mathrm{C} \mathrm{NMR}\left(\mathrm{CDCl}_{3}, 75.468 \mathrm{MHz}\right)$ $\delta: 289.5\left(\mathrm{C}_{\text {carb }}\right), 202.2\left(\left(\mathrm{~W}(\mathrm{CO})_{5}\right)_{\text {trans }}\right), 197.3\left(\left(\mathrm{~W}(\mathrm{CO})_{5}\right)_{\text {cis }}\right), 161.7$ (C5), 135.8 (C4), 146.8 (C3), 154.9 (C2), $78.7\left(\mathrm{CH}_{2}\right), 14.9\left(\mathrm{CH}_{3}\right)$. IR $\left(\mathrm{cm}^{-1}\right.$, hexane, $\left.\nu_{\mathrm{CO}}\right): \mathrm{M}(\mathrm{CO})_{5}: \mathrm{A}_{1}{ }^{(1)} 2070$ and $2065(\mathrm{~m}), \mathrm{B}_{1}$ 1984 (vw), $\mathrm{A}_{1}{ }^{(2)} 1955$ (sh), E 1949 (vs). Calc. $\mathrm{C}_{22} \mathrm{H}_{12} \mathrm{O}_{12} \mathrm{~S}_{2} \mathrm{~W}_{2}$ $\left(899.88 \mathrm{~g} \mathrm{~mol}^{-1}\right) \mathrm{MS}(\mathrm{m} / \mathrm{z}$, intensity (\%)); 898.88 (28\%) $[\mathrm{M}-\mathrm{H}]^{-}$.

Preparation of mixed metal biscarbene complex $\left[\mathrm{Cr}(\mathrm{CO})_{5} \mathrm{C}\right.$ (OEt) $\left.\left\{\mathbf{C}_{6} \mathbf{H}_{2} \mathbf{S}_{2}\right\} \mathbf{C}(\mathbf{O E t}) \mathbf{W}(\mathbf{C O})_{5}\right] \quad$ (5). A solution of $0.23 \mathrm{~mL}$ $(2.2 \mathrm{mmol})$ of thieno[2,3-b]thiophene in $20.0 \mathrm{~mL}$ of THF was treated with $1.40 \mathrm{~mL}(2.2 \mathrm{mmol})$ of $n$-BuLi at $-78{ }^{\circ} \mathrm{C}$ and stirred for 30 minutes. To the solution, $\operatorname{Cr}(\mathrm{CO})_{6}(0.48 \mathrm{~g}$, $2.2 \mathrm{mmol}$ ) was added and stirred for $15 \mathrm{~min}$ at cold temperature and then allowed to reach room temperature over $40 \mathrm{~min}$. At $-78{ }^{\circ} \mathrm{C}$ an additional portion of $1.40 \mathrm{~mL}(2.2 \mathrm{mmol})$ of $n$-BuLi was added and stirred for 30 minutes. The reaction was continued by the addition of $\mathrm{W}(\mathrm{CO})_{6}(0.77 \mathrm{~g}, 2.2 \mathrm{mmol})$, stirred at $-78{ }^{\circ} \mathrm{C}$ for $15 \mathrm{~min}$, before allowing to reach room temperature over $40 \mathrm{~min}$. The solvent was removed in vacuo and the residue dissolved in $10.0 \mathrm{~mL}$ of DCM and cooled to $-20{ }^{\circ} \mathrm{C}$. The reaction mixture was treated with $0.9 \mathrm{~g}(4.7 \mathrm{mmol})$ of $\left[\mathrm{Et}_{3} \mathrm{O}\right]\left[\mathrm{BF}_{4}\right]$ in DCM and allowed to reach room temperature. The reaction mixture was filtered through a small silica gel plug using DCM and the solvent was removed under reduced pressure. The four products were purified by column chromatography using gradient elution with hexane and DCM. Yield: 1: $0.23 \mathrm{~g}$ (0.6 mmol, 27\%), 2: $0.21 \mathrm{~g}$ (0.4 mmol, 18\%), 3: $0.24 \mathrm{~g}$ (0.7 mmol, 17\%) and $0.35 \mathrm{~g}$ of 5 : (0.5 mmol, 21\%).

5: Yield: $0.35 \mathrm{~g}$ (0.5 mmol, 21\%), purple crystals. ${ }^{1} \mathrm{H}$ NMR $\left(\mathrm{CDCl}_{3}, 400.13 \mathrm{MHz}\right) \delta: 8.47$ (s, 1H, H4), 8.39 (s, 1H, H4'), 5.21 (q, $\left.7.0 \mathrm{~Hz}, 2 \mathrm{H}, \mathrm{Cr}\left(\mathrm{CH}_{2}\right)\right), 5.01$ (q, $\left.7.1 \mathrm{~Hz}, 2 \mathrm{H}, \mathrm{W}\left(\mathrm{CH}_{2}\right)\right), 1.70$ (t, $\left.7.0 \mathrm{~Hz}, 3 \mathrm{H}, \mathrm{Cr}\left(\mathrm{CH}_{3}\right)\right), 1.68\left(\mathrm{t}, 7.2 \mathrm{~Hz}, 3 \mathrm{H}, \mathrm{W}\left(\mathrm{CH}_{3}\right)\right) .{ }^{13} \mathrm{C} \mathrm{NMR}$ $\left(\mathrm{CDCl}_{3}, 100.613 \mathrm{MHz}\right) \delta: 315.5\left(\mathrm{C}_{\mathrm{Cr}-\mathrm{carb}}\right), 289.3\left(\mathrm{C}_{\mathrm{W}-\mathrm{carb}}\right), 223.1$ $\left(\left(\mathrm{Cr}(\mathrm{CO})_{5}\right)_{\text {trans }}\right), 216.8\left(\left(\mathrm{Cr}(\mathrm{CO})_{5}\right)_{\text {cis }}\right), 202.2\left(\left(\mathrm{~W}(\mathrm{CO})_{5}\right)_{\text {trans }}\right), 197.3$ ((W(CO) $\left.)_{5 i s}\right), 158.3$ (C5), 135.3 (C4), 147.0 (C3), 154.2 (C2), 161.5 (C5'), $135.9\left(\mathrm{C}^{\prime}\right), 78.7\left(\mathrm{~W}\left(\mathrm{CH}_{2}\right)\right), 76.3\left(\mathrm{Cr}\left(\mathrm{CH}_{2}\right)\right), 15.1(\mathrm{Cr}-$ $\left.\left(\mathrm{CH}_{3}\right)\right)$, $14.9\left(\mathrm{~W}\left(\mathrm{CH}_{3}\right)\right)$. IR $\left(\mathrm{cm}^{-1}\right.$, hexane, $\left.\nu_{\mathrm{CO}}\right): \mathrm{M}(\mathrm{CO})_{5}: \mathrm{A}_{1}{ }^{(1)}$ 2069 and 2058 (m), B 1986 (vw), A $_{1}{ }^{(2)} 1963$ (sh), E 1951 (vs). Calc. $\mathrm{C}_{22} \mathrm{H}_{12} \mathrm{O}_{12} \mathrm{~S}_{2} \mathrm{CrW}\left(767.87 \mathrm{~g} \mathrm{~mol}^{-1}\right) \mathrm{MS}(\mathrm{m} / z$, intensity (\%)); $766.83(6 \%)[\mathrm{M}-\mathrm{H}]^{-}$.

Preparation of the chelated biscarbene complexes: [Cr$\left.\left.\left.(\mathrm{CO})_{4}\{\mathrm{C}(\mathrm{OEt})\}_{2} \mathrm{C}_{4} \mathrm{H}_{2} \mathrm{~S}\right\}\right](6),\left[\mathrm{W}(\mathrm{CO})_{4}\{\mathrm{C}(\mathrm{OEt})\}_{2} \mathrm{C}_{4} \mathrm{H}_{2} \mathrm{~S}\right\}\right]$ (7). LDA was generated in situ from a mixture consisting of $\mathrm{N}^{\mathrm{i}} \mathrm{Pr}_{2} \mathrm{H}$ (0.15 mL, $1.1 \mathrm{mmol}$ and $n$-BuLi $(0.69 \mathrm{~mL}, 1.1 \mathrm{mmol})$ in THF and added dropwise to a solution of 3-bromothiophene $(0.16 \mathrm{~g}, 1.0 \mathrm{mmol})$ in $15 \mathrm{~mL}$ THF at $-90{ }^{\circ} \mathrm{C}$. The solution changed colour to light orange during stirring over a $20 \mathrm{~min}$ time period. Tungsten hexacarbonyl $(0.35 \mathrm{~g}, 1.0 \mathrm{mmol})$ or chromium hexacarbonyl $(0.22 \mathrm{~g}, 1.0 \mathrm{mmol})$ dissolved in $20 \mathrm{~mL}$ THF was added gradually to the reaction mixture. Stirring over a period of $1 \mathrm{~h}$ resulted in a colour change of the reaction mixture to red-brown. $n$-BuLi $(0.69 \mathrm{~mL}, 1.1 \mathrm{mmol})$ in $10 \mathrm{~mL}$ THF was added to the reaction mixture at $-78{ }^{\circ} \mathrm{C}$ and stirring continued for an additional $1 \mathrm{~h}$ while the colour of the solution darkened. The solvent was removed in vacuo and the brown oily residue was dissolved in $30 \mathrm{~mL}$ cold $\left(-30^{\circ} \mathrm{C}\right) \mathrm{DCM}$. The addition of $\left[\mathrm{Et}_{3} \mathrm{O}\right]\left[\mathrm{BF}_{4}\right](0.50 \mathrm{~g}, 2.5 \mathrm{mmol})$ dissolved in $10 \mathrm{~mL}$ DCM, resulted in the reaction mixture changing to an ink-blue colour. Completeness of alkylation was monitored by thin layer chromatography. Three products formed and were purified by column chromatography on silica using hexane as eluent. The first fraction (yellow) collected gave $\left[\mathrm{M}(\mathrm{CO})_{5^{-}}\right.$ $\{\mathrm{C}(\mathrm{OEt}) \mathrm{Bu}\}]$ (less than $3 \%, \mathrm{~W}, \mathrm{Cr})$ and the second $\left[\mathrm{M}(\mathrm{CO})_{5^{-}}\right.$ $\left.\left\{\mathrm{C}(\mathrm{OEt}) \mathrm{C}_{4} \mathrm{H}_{3} \mathrm{~S}\right\}\right](15-17 \%, \mathrm{~W}, \mathrm{Cr}),{ }^{5}$ both known compounds. The third product was the major compound of the reaction and contains a chelating biscarbene ligand, $\left[\mathrm{M}(\mathrm{CO})_{4^{-}}\right.$ $\left.\left.\left.\{\mathrm{C}(\mathrm{OEt})\}_{2} \mathrm{C}_{4} \mathrm{H}_{2} \mathrm{~S}\right\}\right] \mathrm{M}=\mathrm{Cr} \mathbf{6}, \mathrm{W} 7\right) .^{5}$

6: Yield: $0.25 \mathrm{~g}(0.68 \mathrm{mmol}, 68 \%))$, blue crystals. ${ }^{1} \mathrm{H}$ NMR $\left(\mathrm{CDCl}_{3}, 500.139 \mathrm{MHz}\right) \delta: 7.56$ (d, 4.7 Hz, 1H, H5), 6.84 (d, 4.7 $\mathrm{Hz}, 1 \mathrm{H}, \mathrm{H} 4), 4.77$ (q, $\left.7.1 \mathrm{~Hz}, 2 \mathrm{H}, \mathrm{C} 3\left(\mathrm{CH}_{2}\right)\right), 4.75$ (q, $7.1 \mathrm{~Hz}, 2 \mathrm{H}$, C3 $\left.\left(\mathrm{CH}_{2}\right)\right), 1.64\left(\mathrm{t}, 7.1 \mathrm{~Hz}, 3 \mathrm{H}, \mathrm{C} 3\left(\mathrm{CH}_{3}\right)\right), 1.62(\mathrm{t}, 7.1 \mathrm{~Hz}, 3 \mathrm{H}, \mathrm{C} 2$ $\left.\left(\mathrm{CH}_{3}\right)\right) .{ }^{1} \mathrm{H}$ NMR $\left(\mathrm{C}_{6} \mathrm{D}_{6}, 400.13 \mathrm{MHz}\right) \delta: 6.60(\mathrm{~d}, 4.8 \mathrm{~Hz}, 1 \mathrm{H}$, H5), 6.43 (d, $5.1 \mathrm{~Hz}, 1 \mathrm{H}, \mathrm{H} 4), 4.48$ (q, $7.1 \mathrm{~Hz}, 2 \mathrm{H}, \mathrm{C} 3\left(\mathrm{CH}_{2}\right)$ ), 
$4.46\left(\mathrm{q}, 7.1 \mathrm{~Hz}, 2 \mathrm{H}, \mathrm{C} 2\left(\mathrm{CH}_{2}\right)\right), 1.12\left(\mathrm{t}, 7.1 \mathrm{~Hz}, 3 \mathrm{H}, \mathrm{C} 3\left(\mathrm{CH}_{3}\right)\right)$, 1.09 (t, $\left.7.1 \mathrm{~Hz}, 3 \mathrm{H}, \mathrm{C} 2\left(\mathrm{CH}_{3}\right)\right) .{ }^{13} \mathrm{C} \mathrm{NMR}\left(\mathrm{CDCl}_{3}, 125.75 \mathrm{MHz}\right) \delta$ : 320.9 (C3 $\left.3_{\text {carb }}\right), 312.2$ (C2 $\left.{ }_{\text {carb }}\right), 242.5\left(\left(\mathrm{Cr}(\mathrm{CO})_{4}\right)_{\text {trans }}\right), 241.7((\mathrm{Cr}-$ $\left.\left.(\mathrm{CO})_{4}\right)_{\text {trans }}\right), 227.1\left(\left(\mathrm{Cr}(\mathrm{CO})_{4}\right)_{\text {cis }}\right), 167.2$ (C3), $163.2(\mathrm{C} 2)$, 134.6, 116.7 (C5, C4), $76.8\left(\mathrm{C} 3\left(\mathrm{CH}_{2}\right)\right), 76.7\left(\mathrm{C} 2\left(\mathrm{CH}_{2}\right)\right), 15.2,14.3\left(\mathrm{CH}_{3}\right)$. IR $\left(\mathrm{cm}^{-1}\right.$, hexane, $\left.\nu_{\mathrm{CO}}\right): \mathrm{Cr}(\mathrm{CO})_{4}: \mathrm{A}_{1}{ }^{(1)} 2020(\mathrm{~m}), \mathrm{A}_{1}{ }^{(2)} 1964(\mathrm{~s})$, $\mathrm{B}_{1} 1951$ (s), $\mathrm{B}_{2} 1902(\mathrm{~m})$. Anal. Calcd (\%) for $\mathrm{C}_{14} \mathrm{H}_{12} \mathrm{O}_{6} \mathrm{SCr}$ (360.30 $\mathrm{g} \mathrm{mol}^{-1}$ ): C 46.67, H 3.36\%. Found: C 46.84, H 3.45\%.

7: Yield: $0.31 \mathrm{~g}$ (0.63 mmol, 63\%), blue crystals. ${ }^{1} \mathrm{H}$ NMR $\left(\mathrm{C}_{6} \mathrm{D}_{6}, 500.139 \mathrm{MHz}\right) \delta: 6.96(\mathrm{~d}, 5.3 \mathrm{~Hz}, 1 \mathrm{H}, \mathrm{H} 5), 7.31$ (d, 5.1 $\mathrm{Hz}, 1 \mathrm{H}, \mathrm{H} 4), 4.45$ (q, $\left.7.1 \mathrm{~Hz}, 2 \mathrm{H}, \mathrm{C} 3\left(\mathrm{CH}_{2}\right)\right), 4.44$ (q, $7.1 \mathrm{~Hz}, 2 \mathrm{H}$, $\left.\mathrm{C} 2\left(\mathrm{CH}_{2}\right)\right), 1.68$ (t, $\left.7.1 \mathrm{~Hz}, 3 \mathrm{H}, \mathrm{C} 3\left(\mathrm{CH}_{3}\right)\right), 1.65(\mathrm{t}, 7.1 \mathrm{~Hz}, 3 \mathrm{H}, \mathrm{C} 2$ $\left.\left(\mathrm{CH}_{3}\right)\right) .{ }^{13} \mathrm{C}$ NMR $\left(\mathrm{C}_{6} \mathrm{D}_{6}, 125.75 \mathrm{MHz}\right) \delta: 313.9\left(\mathrm{C} 3_{\text {carb }}\right), 283.3$ $\left(\mathrm{C} 2_{\text {carb }}\right)$, n.o. ((W(CO) $\left.\left.)_{4}\right)_{\text {trans }}\right), 201.1\left(\left(\mathrm{~W}(\mathrm{CO})_{4}\right)_{\text {trans }}\right), 191.1((\mathrm{~W}-$ $\left.(\mathrm{CO})_{4}\right)_{\text {cis }}$ ), 164.7 (C3), n.o. (C2), 134.7, 117.7 (C5, C4), 78.6 (C3$\left.\left(\mathrm{CH}_{2}\right)\right), 78.4\left(\mathrm{C} 2\left(\mathrm{CH}_{2}\right)\right), 14.9\left(\mathrm{CH}_{3}\right.$, overlapping $\left.)\right) . \mathrm{IR}\left(\mathrm{cm}^{-1}\right.$, hexane, $\left.\nu_{\mathrm{CO}}\right): \mathrm{M}(\mathrm{CO})_{4}: \mathrm{A}_{1}{ }^{(1)} 2028(\mathrm{~m}), \mathrm{A}_{1}{ }^{(2)} 1956(\mathrm{~s}), \mathrm{B}_{1} 1945(\mathrm{~s})$, $\mathrm{B}_{2} 1892(\mathrm{~m})$. Anal. Calcd (\%) for $\mathrm{C}_{14} \mathrm{H}_{12} \mathrm{O}_{6} \mathrm{SW}$ (492.15 $\mathrm{g} \mathrm{mol}^{-1}$ ): C 34.16, H 2.46\%. Found: C 33.89, H 2.44\%.

Preparation of the chelated biscarbene complexes: [Cr$\left.\left.\left.(\mathrm{CO})_{4}\{\mathrm{C}(\mathrm{OEt})\}_{2} \mathrm{C}_{4} \mathrm{H}_{2} \mathrm{~S}\right\}\right](6),\left[\mathrm{W}(\mathrm{CO})_{4}\{\mathrm{C}(\mathrm{OEt})\}_{2} \mathrm{C}_{4} \mathrm{H}_{2} \mathrm{~S}\right\}\right]$ (7) $[\{\mathrm{Cr}-$ (CO) $\left.\left.)_{4}\{\mathrm{C}(\mathrm{OEt})\}_{2}\right\}_{2} \mathrm{C}_{4} \mathrm{~S}\right](8)\left[\left\{\mathrm{W}(\mathrm{CO})_{4}\{\mathrm{C}(\mathrm{OEt})\}_{2}\right\}_{2} \mathrm{C}_{4} \mathrm{~S}\right]$ (9). To a solution of tetrabromothiophene $(0.40 \mathrm{~g}, 1.0 \mathrm{mmol})$ in $40 \mathrm{~mL}$ THF was cooled to $-78^{\circ} \mathrm{C}$ and $n$-BuLi $(1.25 \mathrm{~mL}$ of a $1.6 \mathrm{M}$ solution in hexane, $2.0 \mathrm{mmol}$ ) was added. Within $5 \mathrm{~min}$, metal hexacarbonyl, $\mathrm{Cr}(\mathrm{CO})_{6}(0.44 \mathrm{~g}, 2 \mathrm{mmol})$ or $\mathrm{W}(\mathrm{CO})_{6}(0.70 \mathrm{~g}$, $2.0 \mathrm{mmol}$ ) was added and the solution was warmed to room temperature and reacted until all the metal carbonyl was converted. The solution was cooled to $-78{ }^{\circ} \mathrm{C}$ and a second portion of $n$-BuLi $(1.25 \mathrm{~mL}, 2.0 \mathrm{mmol})$ was added and the reaction mixture was warmed to room temperature. The solvent was removed in vacuo and the residue dissolved in DCM. An excess $\left[\mathrm{Et}_{3} \mathrm{O}\right]\left[\mathrm{BF}_{4}\right](1.2 \mathrm{~g}, 6.3 \mathrm{mmol})$ was added at $-35^{\circ} \mathrm{C}$ and the alkylation progress monitored by thin layer chromatography. After completion, the DCM was removed and the residue loaded onto a silica gel column and eluted with hexane. Three products separated and yielded $\left[\mathrm{M}(\mathrm{CO})_{5}\{\mathrm{C}(\mathrm{OEt})-\right.$ $\mathrm{Bu}$ \}] (less than 2\%, W, Cr), 6 (0.16 g, 44\% yield) or 7 (0.23 g, $46 \%$ yield) and the third product was the major compound of the reaction and contained two chelating biscarbene ligands, $\left.\left[\left\{\mathrm{M}(\mathrm{CO})_{4}\{\mathrm{C}(\mathrm{OEt})\}_{2}\right\}_{2} \mathrm{C}_{4} \mathrm{~S}\right\}\right] \mathrm{M}=\mathrm{Cr} \mathbf{8}, \mathrm{W}$ 9).

8: Yield: $0.30 \mathrm{~g}(0.47 \mathrm{mmol}, 47 \%))$, blue-black crystals. ${ }^{1} \mathrm{H}$ NMR $\left(\mathrm{CDCl}_{3}, 500.139 \mathrm{MHz}\right) \delta: 4.84\left(\mathrm{q}, 7.1 \mathrm{~Hz}, 2 \mathrm{H}, \mathrm{C} 3\left(\mathrm{CH}_{2}\right)\right)$, $4.76\left(\mathrm{q}, 7.1 \mathrm{~Hz}, 2 \mathrm{H}, \mathrm{C} 3\left(\mathrm{CH}_{2}\right)\right), 1.58\left(\mathrm{t}, 6.9 \mathrm{~Hz}, 3 \mathrm{H}, \mathrm{C} 3\left(\mathrm{CH}_{3}\right)\right)$, $1.56\left(\mathrm{t}, 6.9 \mathrm{~Hz}, 3 \mathrm{H}, \mathrm{C} 2\left(\mathrm{CH}_{3}\right)\right) .{ }^{13} \mathrm{C} \mathrm{NMR}\left(\mathrm{CDCl}_{3}, 125.75 \mathrm{MHz}\right) \delta$ : 316.5 (C $\left.3_{\text {carb }}\right), 301.7$ (C2 $\left.{ }_{\text {carb }}\right), 245.5\left(\left(\mathrm{Cr}(\mathrm{CO})_{4}\right)_{\text {trans }}\right), 239.5((\mathrm{Cr}-$ $\left.\left.(\mathrm{CO})_{4}\right)_{\text {trans }}\right), 226.0\left(\left(\mathrm{Cr}(\mathrm{CO})_{4}\right)_{\text {cis }}\right), 165.0(\mathrm{C} 2), 151.3(\mathrm{C} 3), 77.4(\mathrm{C} 3-$ $\left.\left(\mathrm{CH}_{2}\right)\right)$, $76.4\left(\mathrm{C} 2\left(\mathrm{CH}_{2}\right)\right), 15.2,14.3\left(\mathrm{CH}_{3}\right)$. IR $\left(\mathrm{cm}^{-1}\right.$, hexane, $\left.\nu_{\mathrm{CO}}\right): \mathrm{Cr}(\mathrm{CO})_{4}: \mathrm{A}_{1}{ }^{(1)} 2009(\mathrm{~m}), \mathrm{A}_{1}^{(2)} 1966(\mathrm{~s}), \mathrm{B}_{1} 1946(\mathrm{~s}), \mathrm{B}_{2} 1905$ (m). Anal. Calcd (\%) for $\mathrm{C}_{24} \mathrm{H}_{20} \mathrm{O}_{12} \mathrm{SCr}_{2}\left(636.46 \mathrm{~g} \mathrm{~mol}^{-1}\right)$ : C 45.29, H 3.17\%. Found: C 45.41, H 3.28\%.

9: Yield: $0.39 \mathrm{~g}(0.43 \mathrm{mmol}, 43 \%)$, blue-black crystals. ${ }^{1} \mathrm{H}$ NMR $\left(\mathrm{CDCl}_{3}, 500.139 \mathrm{MHz}\right) \delta 4.58\left(\mathrm{q}, 7.2 \mathrm{~Hz}, 2 \mathrm{H}, \mathrm{C} 3\left(\mathrm{CH}_{2}\right)\right)$, $4.54\left(\mathrm{q}, 7.1 \mathrm{~Hz}, 2 \mathrm{H}, \mathrm{C} 2\left(\mathrm{CH}_{2}\right)\right), 1.62\left(\mathrm{t}, 7.1 \mathrm{~Hz}, 3 \mathrm{H}, \mathrm{C} 3\left(\mathrm{CH}_{3}\right)\right)$, $1.61\left(\mathrm{t}, 7.2 \mathrm{~Hz}, 3 \mathrm{H}, \mathrm{C} 2\left(\mathrm{CH}_{3}\right)\right) .{ }^{1} \mathrm{H}$ NMR $\left(\mathrm{C}_{6} \mathrm{D}_{6}, 500.139 \mathrm{MHz}\right) \delta$ 6.96 (d, 6.9 Hz, 1H, H5), 7.31 (d, $6.9 \mathrm{~Hz}, 1 \mathrm{H}, \mathrm{H} 4), 4.45$ (q, 7.1
$\left.\mathrm{Hz}, 2 \mathrm{H}, \mathrm{C} 3\left(\mathrm{CH}_{2}\right)\right), 4.44\left(\mathrm{q}, 7.1 \mathrm{~Hz}, 2 \mathrm{H}, \mathrm{C} 2\left(\mathrm{CH}_{2}\right)\right), 1.86(\mathrm{t}, 7.1 \mathrm{~Hz}$, $\left.3 \mathrm{H}, \mathrm{C} 3\left(\mathrm{CH}_{3}\right)\right), 1.86\left(\mathrm{t}, 7.1 \mathrm{~Hz}, 3 \mathrm{H}, \mathrm{C} 2\left(\mathrm{CH}_{3}\right)\right) .{ }^{13} \mathrm{C} \mathrm{NMR}\left(\mathrm{C}_{6} \mathrm{D}_{6}\right.$,

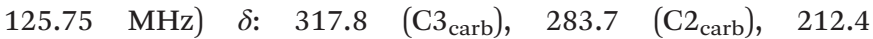
$\left(\left(\mathrm{W}(\mathrm{CO})_{4}\right)_{\text {trans }}\right), 209.1\left(\left(\mathrm{~W}(\mathrm{CO})_{4}\right)_{\text {trans }}\right), 194.8\left(\left(\mathrm{~W}(\mathrm{CO})_{4}\right)_{\text {cis }}\right), 165.4(\mathrm{C} 3)$, $\left.158.3(\mathrm{C} 2), 81.2\left(\mathrm{C} 3\left(\mathrm{CH}_{2}\right)\right), 79.9\left(\mathrm{C} 2\left(\mathrm{CH}_{2}\right)\right), 14.8,14.7\left(\mathrm{CH}_{3}\right)\right)$. IR ( $\mathrm{cm}^{-1}$, hexane, $\left.\nu_{\mathrm{CO}}\right): \mathrm{M}(\mathrm{CO})_{4}: \mathrm{A}_{1}^{(1)} 2017(\mathrm{~m}), \mathrm{A}_{1}^{(2)} 1961(\mathrm{~s}), \mathrm{B}_{1} 1945$ (s), $\quad \mathrm{B}_{2} 1897$ (m). Anal. Calcd (\%) for $\mathrm{C}_{24} \mathrm{H}_{20} \mathrm{O}_{12} \mathrm{SW}_{2}$ (900.15 $\mathrm{g} \mathrm{mol}^{-1}$ ): C 32.08, H 2.24\%. Found: C 32.39, H 2.36\%.

Preparation of the chelated biscarbene complexes: [Cr(CO) $\left.{ }_{4}\{\mathrm{C}(\mathrm{OEt})\}_{2} \mathrm{C}_{6} \mathrm{H}_{2} \mathrm{~S}_{2}\right](10)\left[\mathrm{W}(\mathrm{CO})_{4}\{\mathrm{C}(\mathrm{OEt})\}_{2} \mathrm{C}_{6} \mathrm{H}_{2} \mathrm{~S}_{2}\right](11)$, [Cr$\left.(\mathrm{CO})_{4}\{\mathrm{C}(\mathrm{OEt})\}_{2} \mathrm{C}_{6} \mathrm{H}_{1} \mathrm{~S}_{2}\{\mathrm{C}(\mathrm{OEt})\} \mathrm{Cr}(\mathrm{CO})_{5}\right](12),\left[\mathrm{W}(\mathrm{CO})_{4}\{\mathrm{C}(\mathrm{OEt})\}_{2^{-}}\right.$ $\left.\mathrm{C}_{6} \mathrm{H}_{1} \mathrm{~S}_{2}\{\mathrm{C}(\mathrm{OEt})\} \mathrm{W}(\mathrm{CO})_{5}\right] \quad(13), \quad\left[\left\{\mathrm{Cr}(\mathrm{CO})_{4}\{\mathrm{C}(\mathrm{OEt})\}_{2}\right\}_{2} \mathrm{C}_{6} \mathrm{~S}_{2}\right] \quad$ (14) $\left[\left\{\mathbf{W}(\mathbf{C O})_{4}\{\mathbf{C}(\mathbf{O E t})\}_{2}\right\}_{2} \mathbf{C}_{6} \mathbf{S}_{2}\right](\mathbf{1 5})$. A solution of $4,4^{\prime}, 5,5^{\prime}$-tetrabromothieno[2,3- $b$ ] thiophene $(1.14 \mathrm{~g}, 2.5 \mathrm{mmol})$ in THF was cooled to $-78{ }^{\circ} \mathrm{C}$ and treated with $4.29 \mathrm{~mL}$ (6.0 mmol) $n$-BuLi. The reaction mixture almost immediately changed to yellow. Within five minutes the metal carbonyl $\operatorname{Cr}(\mathrm{CO})_{6}(1.10 \mathrm{~g}$, $5.0 \mathrm{mmol})$ or $\mathrm{W}(\mathrm{CO})_{6}(1.76 \mathrm{~g}, 5.0 \mathrm{mmol})$ was added, and the solution was heated quickly to RT and stirred until all the metal carbonyl dissolved. A second portion of $n$-BuLi, $4.29 \mathrm{~mL}$ $(6.0 \mathrm{mmol})$ was added at $-78{ }^{\circ} \mathrm{C}$, after which the solution was heated to room temperature. The solvent was removed in vacuo and the residue dissolved in $10 \mathrm{~mL}$ of dichloromethane and cooled to $-20^{\circ} \mathrm{C}$. Alkylation was done with $4.50 \mathrm{~g}(23.7 \mathrm{mmol})$ of $\left[\mathrm{Et}_{3} \mathrm{O}\right]\left[\mathrm{BF}_{4}\right]$ in DCM and the reaction mixture was allowed to rise to room temperature. The solvent was removed in vacuo and the reaction mixture wet loaded on a silica gel column. The products were separated using flash chromatography and gradient elution with hexane and DCM.

In addition to 12 and $14,0.05 \mathrm{~g}$ of $3(0.075 \mathrm{mmol}, 3 \%)$ and trace amounts of $\mathbf{1 0}$ were isolated for the reaction with chromium. The reaction with tungsten yielded 13 and 15, along with $0.09 \mathrm{~g}$ of 4 (0.1 mmol, 4\%) and $0.01 \mathrm{~g}$ (0.025 mmol, 1\%) of 11.

10: Yield: trace amounts, red solids. ${ }^{1} \mathrm{H} \mathrm{NMR}\left(\mathrm{CDCl}_{3}\right.$, $300.13 \mathrm{MHz}$ ) $\delta: 7.45$ (d, $5.3 \mathrm{~Hz}, 1 \mathrm{H}, \mathrm{H}^{\prime}$ ), 7.39 (d, $5.3 \mathrm{~Hz}, 1 \mathrm{H}$, $\mathrm{H}^{\prime}$ ), 4.84 (q, $\left.7.1 \mathrm{~Hz}, 2 \mathrm{H}, \mathrm{C} 7\left(\mathrm{CH}_{2}\right)\right), 4.73(\mathrm{q}, 7.1 \mathrm{~Hz}, 2 \mathrm{H}$, C6 $\left.\left(\mathrm{CH}_{2}\right)\right), 1.62\left(\mathrm{t}, 7.1 \mathrm{~Hz}, 3 \mathrm{H}, \mathrm{C} 7\left(\mathrm{CH}_{3}\right)\right), 1.62(\mathrm{t}, 7.1 \mathrm{~Hz}, 3 \mathrm{H}$, $\left.\mathrm{C} 6\left(\mathrm{CH}_{3}\right)\right) .{ }^{13} \mathrm{C}$ NMR $\left(\mathrm{CDCl}_{3}, 75.468 \mathrm{MHz}\right)$ not enough sample.

11: Yield: $0.01 \mathrm{~g}$ (0.025 mmol, $1 \%)$, red solids. ${ }^{1} \mathrm{H}$ NMR $\left(\mathrm{CDCl}_{3}, 300.13 \mathrm{MHz}\right)$ \&: 7.49 (d, $\left.5.3 \mathrm{~Hz}, 1 \mathrm{H}, \mathrm{H}^{\prime}\right), 7.45$ (d, 5.3 $\left.\mathrm{Hz}, 1 \mathrm{H}, \mathrm{H} 4^{\prime}\right), 4.52$ (q, $\left.7.1 \mathrm{~Hz}, 2 \mathrm{H}, \mathrm{C} 7\left(\mathrm{CH}_{2}\right)\right), 4.49$ (q, $7.1 \mathrm{~Hz}, 2 \mathrm{H}$, C6 $\left.\left(\mathrm{CH}_{2}\right)\right), 1.70$ (t, 7.1 Hz, 3H, C7 $\left.\left(\mathrm{CH}_{3}\right)\right), 1.61$ (t, $7.1 \mathrm{~Hz}, 3 \mathrm{H}, \mathrm{C} 6$ $\left.\left(\mathrm{CH}_{3}\right)\right) .{ }^{13} \mathrm{C} \mathrm{NMR}\left(\mathrm{CDCl}_{3}, 75.468 \mathrm{MHz}\right) \delta 289.3$ (C7 $\left.7_{\text {carb}}\right), 281.8$ $\left(\mathrm{C6}_{\text {carb }}\right), 220.4$ and $220.2\left(\left(\mathrm{~W}(\mathrm{CO})_{4}\right)_{\text {trans }}\right), 212.4\left(\left(\mathrm{~W}(\mathrm{CO})_{4}\right)_{\text {cis }}\right)$, 171.4 (C5), 160.2 (C4), 136.6, n.o. (C3, C2), 130.5 (C5'), 121.9 (C4'), $79.8\left(\mathrm{C} 7\left(\mathrm{CH}_{2}\right)\right), 79.4\left(\mathrm{C}^{\prime}\left(\mathrm{CH}_{2}\right)\right), 14.8\left(\mathrm{C} 7\left(\mathrm{CH}_{3}\right)\right), 14.7(\mathrm{C} 6-$ $\left.\left(\mathrm{CH}_{3}\right)\right)$. IR $\left(\mathrm{cm}^{-1}\right.$, hexane, $\left.\nu_{\mathrm{CO}}\right): \mathrm{M}(\mathrm{CO})_{4}: \mathrm{A}_{1}{ }^{(1)} 2028(\mathrm{~m}), \mathrm{A}_{1}{ }^{(2)}$ 1960 (vs), B 1959 (sh), $\mathrm{B}_{2} 1894$ (m). Calc C ${ }_{16} \mathrm{H}_{12} \mathrm{O}_{6} \mathrm{~S}_{2} \mathrm{~W}$ (547.96 $\mathrm{g} \mathrm{mol}^{-1}$ ) MS ( $\mathrm{m} / \mathrm{z}$, intensity (\%)); 606.91 (5\%) [M + MF $-\mathrm{H}]^{-}$(MF = methyl formate).

12: Yield: $0.38 \mathrm{~g}$ (0.6 mmol, 23\%), purple-black crystals. ${ }^{1} \mathrm{H}$ NMR $\left(\mathrm{CDCl}_{3}, 300.13 \mathrm{MHz}\right) \delta: 8.61$ (s, 1H, H4') 5.20 (q, $7.0 \mathrm{~Hz}$, $\left.2 \mathrm{H}, \mathrm{C6}^{\prime}\left(\mathrm{CH}_{2}\right)\right), 4.71$ (q, $\left.7.1 \mathrm{~Hz}, 2 \mathrm{H}, \mathrm{C} 7\left(\mathrm{CH}_{2}\right)\right), 4.66(\mathrm{q}, 7.1 \mathrm{~Hz}$, 2H, C6 $\left.\left(\mathrm{CH}_{2}\right)\right), 1.77$ (t, 7.1 Hz, 3H, C6' $\left.\left(\mathrm{CH}_{3}\right)\right), 1.69$ (t, $7.0 \mathrm{~Hz}, 3 \mathrm{H}$, $\left.\mathrm{C} 7\left(\mathrm{CH}_{3}\right)\right), 1.59\left(\mathrm{t}, 7.1 \mathrm{~Hz}, 3 \mathrm{H}, \mathrm{C} 6\left(\mathrm{CH}_{3}\right)\right) .{ }^{13} \mathrm{C} \mathrm{NMR}\left(\mathrm{CDCl}_{3}\right.$, 
$75.468 \mathrm{MHz}) \delta: 315.1$ ( $\left.\mathrm{C6}_{\text {carb }}{ }_{\text {carb }}\right), 314.9$ (C7 $\left.{ }_{\text {carb}}\right), 307.2$ (C6 $\left.6_{\text {carb }}\right)$, 243.8 and $243.5\left(\left(\mathrm{Cr}(\mathrm{CO})_{4}\right)_{\text {trans }}\right), 228.1\left(\left(\mathrm{Cr}(\mathrm{CO})_{4}\right)_{\text {cis }}\right), 223.0((\mathrm{Cr}-$ $\left.\left.(\mathrm{CO})_{5}\right)_{\text {trans }}\right), 216.7\left(\left(\mathrm{Cr}(\mathrm{CO})_{5}\right)_{\text {cis }}\right), 158.6$ (C5), $156.9(\mathrm{C} 4), 135.9$, 154.4 (C3, C2), 164.4 (C5'), $135.8\left(\mathrm{C}^{\prime}\right), 77.2\left(\mathrm{C6}^{\prime}\left(\mathrm{CH}_{2}\right)\right), 76.8$ $\left(\mathrm{C} 7\left(\mathrm{CH}_{2}\right)\right), 76.2\left(\mathrm{C} 6\left(\mathrm{CH}_{2}\right)\right), 15.1\left(\mathrm{C6}^{\prime}\left(\mathrm{CH}_{3}\right)\right), 15.1\left(\mathrm{C} 7\left(\mathrm{CH}_{3}\right)\right), 15.0$ $\left(\mathrm{C} 6\left(\mathrm{CH}_{3}\right)\right)$. IR $\left(\mathrm{cm}^{-1}\right.$, hexane, $\left.\nu_{\mathrm{CO}}\right): \mathrm{M}(\mathrm{CO})_{5}: \mathrm{A}_{1}^{(1)} 2059(\mathrm{~m}), \mathrm{B}_{1}$ 1989 (vw), $\mathrm{A}_{1}{ }^{(2)} 1951$ (sh), E 1951 (vs), M(CO) : $^{{ }_{1}{ }^{(1)}} 2021$ (m), $\mathrm{A}_{1}{ }^{(2)} 1968$ (vs), $\mathrm{B}_{1} 1964$ (sh), $\mathrm{B}_{2} 1903$ (m). Calc. $\mathrm{C}_{24} \mathrm{H}_{16} \mathrm{O}_{12} \mathrm{~S}_{2} \mathrm{Cr}_{2}$ (663.89 $\left.\mathrm{g} \mathrm{mol}^{-1}\right) \mathrm{MS}\left(\mathrm{m} / \mathrm{z}\right.$, intensity (\%)); $662.88(9 \%)[\mathrm{M}-\mathrm{H}]^{-}$.

13: Yield: $0.44 \mathrm{~g}$ (0.5 mmol, $19 \%)$, purple-black crystals. ${ }^{1} \mathrm{H}$ $\mathrm{NMR}\left(\mathrm{CDCl}_{3}, 300.13 \mathrm{MHz}\right) \delta: 8.59\left(\mathrm{~s}, 1 \mathrm{H}, \mathrm{H} 4^{\prime}\right), 5.00(\mathrm{q}, 7.1 \mathrm{~Hz}$, 2H, C6' $\left.\left(\mathrm{CH}_{2}\right)\right), 4.44$ (q, $\left.7.1 \mathrm{~Hz}, 2 \mathrm{H}, \mathrm{C} 7\left(\mathrm{CH}_{2}\right)\right), 4.43$ (q, $7.1 \mathrm{~Hz}$, 2H, C6 $\left.\left(\mathrm{CH}_{2}\right)\right), 1.78$ (t, $\left.7.1 \mathrm{~Hz}, 3 \mathrm{H}, \mathrm{C6}^{\prime}\left(\mathrm{CH}_{3}\right)\right), 1.68(\mathrm{t}, 7.1 \mathrm{~Hz}, 3 \mathrm{H}$, $\left.\mathrm{C} 7\left(\mathrm{CH}_{3}\right)\right), 1.60\left(\mathrm{t}, 7.1 \mathrm{~Hz}, 3 \mathrm{H}, \mathrm{C} 6\left(\mathrm{CH}_{3}\right)\right) .{ }^{13} \mathrm{C} \mathrm{NMR}\left(\mathrm{CDCl}_{3}\right.$, $75.468 \mathrm{MHz}) \delta: 289.3$ (C6 ${ }_{\text {carb }}$ ), 286.9 ( $\left.\mathrm{C}_{\text {carb }}\right), 279.8$ (C6 $\left.{ }_{\text {carb }}\right)$, 220.5 and $220.1\left(\left(\mathrm{~W}(\mathrm{CO})_{4}\right)_{\text {trans }}\right), 212.4\left(\left(\mathrm{~W}(\mathrm{CO})_{4}\right)_{\text {cis }}\right), 202.1((\mathrm{~W}-$ $\left.\left.(\mathrm{CO})_{5}\right)_{\text {trans }}\right), 197.2\left(\left(\mathrm{~W}(\mathrm{CO})_{5}\right)_{\text {cis }}\right), 161.7$ (C5), $160.8(\mathrm{C} 4), 137.3$, 155.0 (C3, C2), 171.3 (C5'), $136.7\left(\mathrm{C}^{\prime}\right), 80.1\left(\mathrm{C6}^{\prime}\left(\mathrm{CH}_{2}\right)\right), 79.6$ $\left(\mathrm{C} 7\left(\mathrm{CH}_{2}\right)\right), 78.7\left(\mathrm{C} 6\left(\mathrm{CH}_{2}\right)\right), 14.9\left(\mathrm{C6}^{\prime}\left(\mathrm{CH}_{3}\right)\right), 14.8\left(\mathrm{C} 7\left(\mathrm{CH}_{3}\right)\right), 14.7$ $\left(\mathrm{C} 6\left(\mathrm{CH}_{3}\right)\right)$. IR $\left(\mathrm{cm}^{-1}\right.$, hexane, $\left.\nu_{\mathrm{CO}}\right): \mathrm{M}(\mathrm{CO})_{5}: \mathrm{A}_{1}{ }^{(1)} 2066(\mathrm{~m}), \mathrm{B}_{1}$ 1986 (vw), $\mathrm{A}_{1}^{\left({ }^{(2)}\right.} 1947$ (sh), E 1947 (vs), M(CO) : $_{4} \mathrm{~A}_{1}{ }^{(1)} 2027$ (m), $\mathrm{A}_{1}{ }^{(2)} 1961$ (vs), $\mathrm{B}_{1} 1947$ (sh), $\mathrm{B}_{2} 1895$ (m). Calc. $\mathrm{C}_{24} \mathrm{H}_{16} \mathrm{O}_{12} \mathrm{~S}_{2} \mathrm{~W}_{2}$ (927.91 $\left.\mathrm{g} \mathrm{mol}^{-1}\right) \mathrm{MS}\left(\mathrm{m} / \mathrm{z}\right.$, intensity (\%)); $926.92(3 \%)[\mathrm{M}-\mathrm{H}]^{-}$.

14: Yield: $0.71 \mathrm{~g}(1.0 \mathrm{mmol}, 41 \%)$, blue-black crystals. ${ }^{1} \mathrm{H}$ NMR $\left(\mathrm{CDCl}_{3}, 300.13 \mathrm{MHz}\right) \delta: 4.73\left(\mathrm{q}, 7.1 \mathrm{~Hz}, 4 \mathrm{H}, \mathrm{C} 7\left(\mathrm{CH}_{2}\right)\right)$, 4.70 (q, $\left.7.1 \mathrm{~Hz}, 4 \mathrm{H}, \mathrm{C} 6\left(\mathrm{CH}_{2}\right)\right), 1.61$ (t, $\left.7.1 \mathrm{~Hz}, 6 \mathrm{H}, \mathrm{C} 7\left(\mathrm{CH}_{3}\right)\right)$, $1.54\left(\mathrm{t}, 7.1 \mathrm{~Hz}, 6 \mathrm{H}, \mathrm{C} 6\left(\mathrm{CH}_{3}\right)\right) .{ }^{13} \mathrm{C} \mathrm{NMR}\left(\mathrm{CDCl}_{3}, 75.468 \mathrm{MHz}\right) \delta$ : 319.5 (C7 carb$\left._{1}\right), 310.7$ (C6 $\left.6_{\text {carb }}\right), 242.3$ and $239.4\left(\left(\mathrm{Cr}(\mathrm{CO})_{4}\right)_{\text {trans }}\right)$, $227.7\left(\left(\mathrm{Cr}(\mathrm{CO})_{4}\right)_{c i s}\right), 164.1$ (C5), 159.8 (C4), n.o. (C3, C2), 77.2 $\left(\mathrm{C} 7\left(\mathrm{CH}_{2}\right)\right), 76.4\left(\mathrm{C} 6\left(\mathrm{CH}_{2}\right)\right), 15.0\left(\mathrm{C} 7\left(\mathrm{CH}_{3}\right)\right), 14.8\left(\mathrm{C} 6\left(\mathrm{CH}_{3}\right)\right)$. IR $\left(\mathrm{cm}^{-1}\right.$, hexane, $\left.\nu_{\mathrm{CO}}\right): \mathrm{M}(\mathrm{CO})_{4}: \mathrm{A}_{1}^{(1)} 2021$ and $2009(\mathrm{~m}), \mathrm{A}_{1}{ }^{(2)}$ 1955 (vs), $\mathrm{B}_{1} 1945$ (sh), $\mathrm{B}_{2} 1888$ (m). Calc. $\mathrm{C}_{26} \mathrm{H}_{20} \mathrm{O}_{12} \mathrm{~S}_{2} \mathrm{Cr}_{2}$ (691.92 $\left.\mathrm{g} \mathrm{mol}^{-1}\right) \mathrm{MS}\left(\mathrm{m} / \mathrm{z}\right.$, intensity (\%)); $690.90(4 \%)[\mathrm{M}-\mathrm{H}]^{-}$.

15: Yield: $1.03 \mathrm{~g}$ (1.1 mmol, 43\%), blue-black crystals. ${ }^{1} \mathrm{H}$ NMR $\left(\mathrm{CDCl}_{3}, 400.13 \mathrm{MHz}\right) \delta: 4.49$ (q, $\left.7.1 \mathrm{~Hz}, 4 \mathrm{H}, \mathrm{C} 7\left(\mathrm{CH}_{2}\right)\right)$, $4.43\left(\mathrm{q}, 7.1 \mathrm{~Hz}, 2 \mathrm{H}, \mathrm{C} 6\left(\mathrm{CH}_{2}\right)\right), 1.61\left(\mathrm{t}, 7.1 \mathrm{~Hz}, 6 \mathrm{H}, \mathrm{C} 7\left(\mathrm{CH}_{3}\right)\right)$, $1.54\left(\mathrm{t}, 7.1 \mathrm{~Hz}, 6 \mathrm{H}, \mathrm{C} 6\left(\mathrm{CH}_{3}\right)\right) .{ }^{13} \mathrm{C} \mathrm{NMR}\left(\mathrm{CDCl}_{3}, 100.613 \mathrm{MHz}\right)$ $\delta: 293.8\left(\mathrm{C}_{\text {carb }}\right), 283.7$ ( $\left.\mathrm{C}_{\text {carb }}\right), 219.5$ and $217.2\left(\left(\mathrm{~W}(\mathrm{CO})_{4}\right)_{\text {trans }}\right)$, $211.6\left(\left(\mathrm{~W}(\mathrm{CO})_{4}\right)_{c i s}\right), 170.0$ (C5), 163.5 (C4), n.o., 155.0 (C3, C2), $79.8\left(\mathrm{C} 7\left(\mathrm{CH}_{2}\right)\right), 79.6\left(\mathrm{C} 6\left(\mathrm{CH}_{2}\right)\right), 14.7\left(\mathrm{C} 7\left(\mathrm{CH}_{3}\right)\right), 14.5\left(\mathrm{C} 6\left(\mathrm{CH}_{3}\right)\right)$. IR $\left(\mathrm{cm}^{-1}\right.$, hexane, $\left.\nu_{\mathrm{CO}}\right): \mathrm{M}(\mathrm{CO})_{4}: \mathrm{A}_{1}{ }^{(1)} 2029$ and $2018(\mathrm{~m}), \mathrm{A}_{1}{ }^{(2)}$ 1950 (vs), $\mathrm{B}_{1} 1938$ (sh), $\mathrm{B}_{2} 1874$ (m). Calc. $\mathrm{C}_{26} \mathrm{H}_{20} \mathrm{O}_{12} \mathrm{~S}_{2} \mathrm{~W}_{2}$ $\left(955.94 \mathrm{~g} \mathrm{~mol}^{-1}\right) \mathrm{MS}(\mathrm{m} / \mathrm{z}$, intensity (\%)); 954.97 (28\%) $[\mathrm{M}-\mathrm{H}]^{-}$.

\section{Conclusions}

A series of novel Fischer multicarbene complexes could be synthesized by using deprotonation, lithium-halogen exchange and stepwise lithiation reactions along with the removal of bromine by alkylating with excess triethyloxonium tetrafluoroborate. Examples of these are demonstrated by the preparation of complexes with monocarbene-, chelating biscarbene- and mixed metal biscarbene-ligands. Both the number of Fischer carbene moieties and different types of carbene units on a single thieno[2,3- $b]$ thiophene backbone are without precedent in Fischer carbene complex chemistry. Blocking one side of a thiophene backbone by a fused second thiophene ring in a 2,3- $b$ fashion has electronic and geometric consequences. The triscarbene complexes $\mathbf{1 2}$ and $\mathbf{1 3}$ are exceptional and the presence of three electronically different carbene carbons creates the opportunity for selective and diverse reactivity patterns. The formation of the analogous triscarbene complex of thiophene was not observed, which we ascribe to the absence of inter-ring conjugation in thieno[2,3-b]thiophene. Also unique in Fischer carbene chemistry is the fusion of four 5-membered rings with the two biscarbene chelate rings at the termini of the thieno[2,3- $b]$ thiophene linker, affording a curved macromolecule that describes a semicircle. Solid state structures confirmed the stabilization of multicarbene complexes as a result of two carbene ligands being part of a chelate ring and a rigid planar linker between the metal carbonyl fragments. In spite of steric congestion, $\mathbf{8}$ and $\mathbf{9}$ are stable in the solid state. Complexes 5, 7, 13 and 15 display intermolecular interactions and different packing phenomena, because of the different types of carbene ligands.

\section{Acknowledgements}

We are grateful for assistance by Mr E. R. Palmer (NMR) and Dr D. Koot (MS). This work was supported financially by the National Research Foundation (NRF) of South Africa with grants to SL (no. 73679 and 77079) and DIB (no. 87890 and 92521).

\section{References}

1 For reviews see: (a) H. G. Raubenheimer, Dalton Trans., 2014, 43, 16959-16973; (b) J. W. Herndon, Coord. Chem. Rev., 2013, 257, 2800-3003, and previous annual reviews; (c) Metal Carbenes in Organic Synthesis, Top. Organomet. Chem, ed. K. H. Dötz, Springer-Verlag, Berlin, Heidelberg, 2004, vol. 13.

2 (a) D. J. Nelson, Eur. J. Inorg. Chem., 2015, 2012-2027; (b) P. de Fremont, N. Marion and S. P. Nolan, Coord. Chem. Rev., 2009, 253, 862-892; (c) J. A. Mata, F. E. Hahn and E. Peris, Chim. Sci., 2014, 5, 1723-1732.

3 (a) E. O. Fischer, W. Röll, U. Schubert and K. Ackermann, Angew. Chem., Int. Ed. Engl., 1981, 20, 611-612; (b) E. O. Fischer, W. Röll, N. H. T. Huy and K. Ackermann, Chem. Ber., 1982, 115, 2951-2964; (c) K. Öfele, F. Dyckhoff and H. G. Krist, Chem. Ber., 1993, 126, 2573-2578; (d) N. H. T. Huy, E. O. Fischer, J. Riede, U. Thewalt and K. H. Dötz, J. Organomet. Chem., 1984, 273, C29-C32.

4 N. H. T. Huy, C. Pascard, E. T. h. Dau and K. H. Dötz, Organometallics, 1988, 7, 590-592.

5 (a) N. A. van Jaarsveld, D. C. Liles and S. Lotz, Dalton Trans., 2010, 39, 5777-5779; (b) S. Lotz, N. A. van Jaarsveld, 
D. C. Liles, C. Crause, H. Görls and Y. M. Terblans, Organometallics, 2012, 31, 5371-5383.

6 (a) J. Roncali, Chem. Rev., 1992, 92, 711-738; (b) Handbook of Oligo- and Polythiophenes, ed. D. Fichou, Wiley-VCH, Weinheim, Germany, 1999; (c) P. Bäuerle, in Oligothiophenes in Electronic Materials: The Oligomeric Approach, ed. G. Wegner and K. Müllen, Wiley-VCH, Weinheim, 1998.

7 (a) W. Jiang, Y. Li and Z. Wang, Chem. Soc. Rev., 2013, 42, 6113-6127; (b) I. P. Perepichka, D. F. Perepichka, H. Meng and F. Wudl, Adv. Mater., 2005, 17, 2281-2305; (c) J. Youn, P.-Y. Huang, Y.-W. Huang, M.-c. chen, Y.-J. Lin, H. Huang, R. P. Ortiz, C. Stern, M.-C. Chung, C.-Y. Feng, L.-H. Chen, A. Facchetti and T. J. Marks, Adv. Funct. Mater., 2012, 27, 48-60.

8 (a) R. J. Angelici, Coord. Chem. Rev., 1990, 105, 61-76; (b) T. B. Rauchfuss, Prog. Inorg. Chem., 1991, 39, 259-329;

(c) S. Lotz, P. H. van Rooyen and R. Meyer, Adv. Organomet. Chem., 1995, 37, 219-320; (d) S. Lotz, C. Crause, A. J. Olivier, D. C. Liles, H. Görls, M. Landman and D. I. Bezuidenhout, Dalton Trans., 2009, 697-710.

9 (a) M. Landman, H. Görls and S. Lotz, J. Organomet. Chem., 2001, 617-618, 280-287; (b) M. Landman, H. Görls and S. Lotz, Eur. J. Inorg. Chem., 2001, 233-238; (c) M. Landman, H. Görls and S. Lotz, Z. Anorg. Allg. Chem., 2002, 628, 2037-2043.

10 (a) D. I. Bezuidenhout, S. Lotz, D. C. Liles and B. van der Westhuizen, Coord. Chem. Rev., 2012, 256, 479-524; (b) M. P. López-Alberca, M. J. Mancheño, I. Fernández, M. Gómez-Gallego, M. A. Sierra, C. Hemmert and H. Gornitzka, Eur. J. Inorg. Chem., 2011, 842-849; (c) C. Hartbaum, G. Roth and H. Fischer, Eur. J. Inorg. Chem., 1998, 191-202; (d) L. Quast, M. Nieger and K. H. Dötz, Organometallics, 2000, 19, 2179-2183.
11 T. Otsubo, Y. Kono, N. Hozo, H. Miyamoto, Y. Aso, F. Ogura, T. Tanaka and M. Sawada, Bull. Chem. Soc. Jpn., 1993, 66, 2033-2041.

12 V. Fiandanese, D. Bottalico, G. Marchese and A. Punzi, Tetrahedron, 2006, 62, 5126-5132.

13 C. Crause, H. Görls and S. Lotz, Dalton Trans., 2005, 16491657.

14 J. Barluenga, A. A. Trabanco, I. Pérez-Sánchez, R. de la Campa, J. Flórez, S. García-Granda and A. Aguirre, Chem. Eur. J., 2008, 14, 5401-5404.

15 P. Fournari and P. Meunier, Bull. Soc. Chim. Fr., 1974, 3-4, 583-586.

16 (a) F. W. Evans, R. J. Fox and M. Szwarc, J. Am. Chem. Soc., 1960, 82, 6414-6415; (b) M. J. Diem, D. F. Burow and J. L. Fry, J. Org. Chem., 1977, 42, 1801-1802.

17 S. Gronowitz and B. Persson, Acta Chem. Scand., 1967, 21, 812-813.

18 M. Hesse, H. Meier and B. Zeeh, Spektroskopische Methoden in der organischen Chemie, Georg Thieme Verlag, Stuttgart, 1984, p. 153.

19 D. M. Adams, Metal-Ligand and Related Vibrations, Edward Arnold Publishers Ltd, London, 1967, pp. 98-101.

20 C. P. Brock and J. D. Dunitz, Chem. Mater., 1994, 6, 11181127.

21 L. Brandsma, S. F. Vasilevsky and H. D. Verkruijsse, Application of transition metal catalysts in organic synthesis, Springer, Berlin, 1998, pp. 25-26.

22 H. Meerwein, Org. Synth., 1966, 46, 113-115.

23 APEX2 (including SAINT and SADABS), BrukerAXS Inc., Madison, WI, 2015.

24 G. M. Sheldrick, Acta Crystallogr., Sect. A: Fundam. Crystallogr., 2015, 71, 3-8.

25 G. M. Sheldrick, Acta Crystallogr., Sect. C: Cryst. Struct. Commun., 2015, 71, 3-8. 